\title{
Verification of MELCOR Input Decks Used in ITER RPrS Analyses
}

\author{
Richard L. Moore \\ January 2008
}

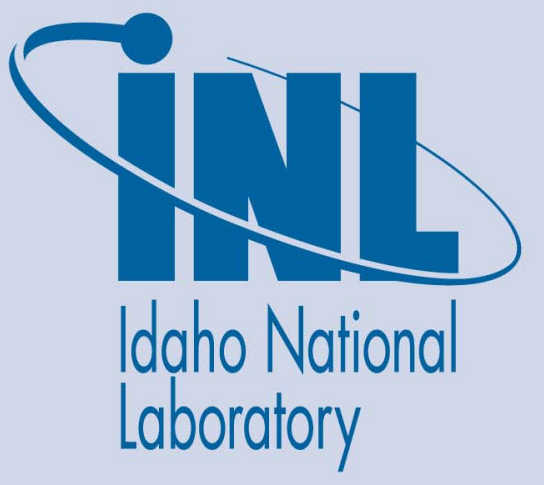

The INL is a U.S. Department of Energy National Laboratory operated by Battelle Energy Alliance 
INL/EXT-07-13305

\title{
Verification of MELCOR Input Decks Used in ITER RPrS Analyses
}

\author{
Richard L. Moore
}

January 2008

\begin{abstract}
Idaho National Laboratory
Idaho Falls, Idaho 83415
\end{abstract}

Prepared for the

U.S. Department of Energy

Office of Science

Under DOE Idaho Operations Office

Contract DE-AC07-05ID14517 
Verification of MELCOR Input Decks Used in ITER PrS Analyses

INL/EXT-07-13305

January 2008

Approved by

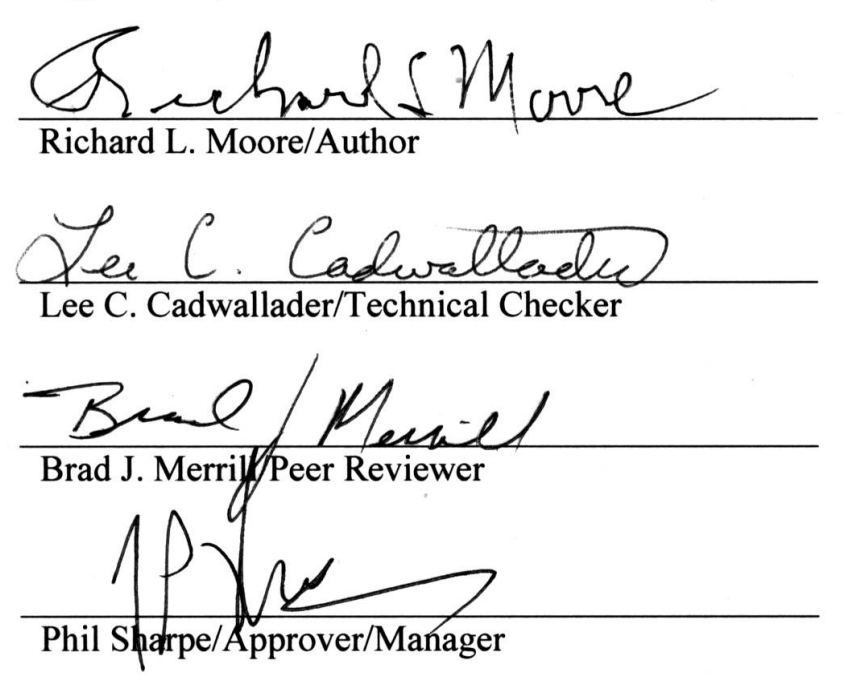

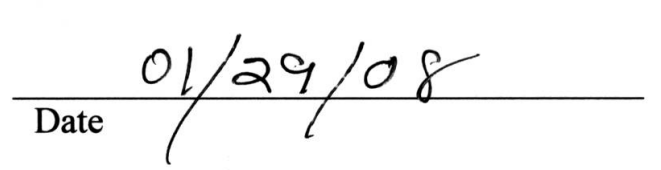
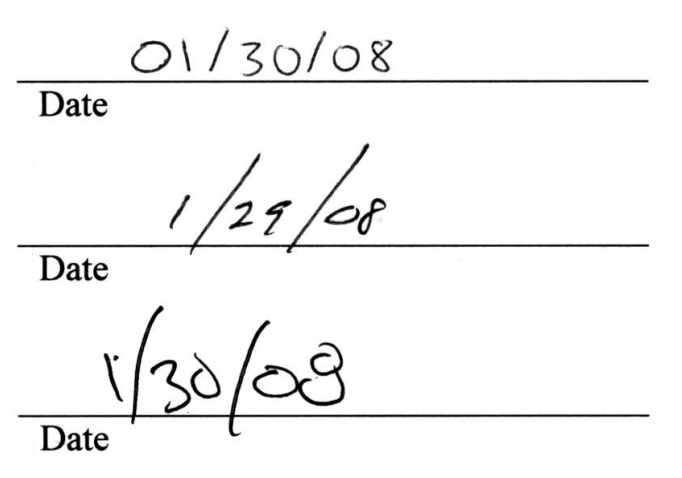


\section{ABSTRACT}

This report as part of an ITER Task Agreement, documents the verification of the MELCOR Input Computer Decks used in performing the required safety analyses to be presented in the Preliminary Safety Report (Rapport Préliminaire de Séreté, RPrS). 


\section{ACRONYMS}

$\begin{array}{ll}\text { AAS } & \text { Accident Analysis Specifications } \\ \text { BDBA } & \text { Beyond Design Basis Accident } \\ \text { BLK } & \text { Blanket } \\ \text { CV } & \text { Control Volume } \\ \text { CF } & \text { Control Function } \\ \text { DBA } & \text { Design Basis Accident } \\ \text { FP } & \text { Flow Path } \\ \text { FW } & \text { First Wall } \\ \text { HS } & \text { Heat Structure } \\ \text { HX } & \text { Heat Exchanger } \\ \text { IDM } & \text { ITER Document Management } \\ \text { ITER } & \text { International Thermonuclear Experimental Reactor } \\ \text { PHTS } & \text { Primary Heat Transport System } \\ \text { RPrS } & \text { Preliminary Safety Report } \\ \text { VV } & \text { Vacuum Vessel } \\ \text { SADL } & \text { Safety Analysis Data List } \\ \text { TCWS } & \text { Tokomak Coolant Water System } \\ & \end{array}$





\section{CONTENTS}

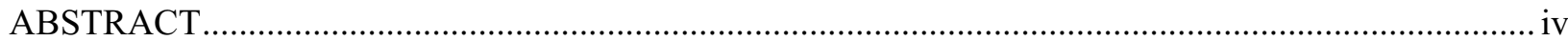

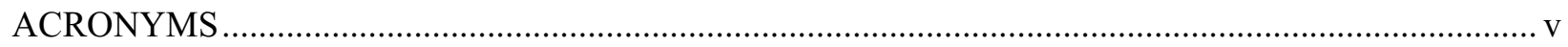

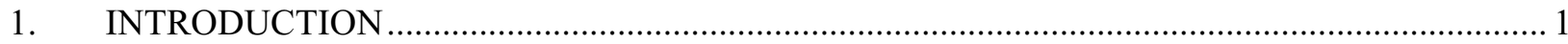

2. COMPUTER DECK FOR THE COOLANT LEAK IN THE PORT CELL NORMAL EVENT ..... 2

3. COMPUTER DECK FOR THE COOLANT LEAK IN THE PORT CELL BAKING EVENT....... 9

4. COMPUTER DECK FOR CRYOSTAT WATER INGRESS EVENT ........................................ 12

5. COMPUTER DECK FOR LARGE DIVERTOR EX-VESSEL PIPE BREAK EVENT ................ 17

6. COMPUTER DECK FOR LOSS OF VACUUM DRY-BYPASS EVENT .................................2 21

7. COMPUTER DECK FOR MULTIPLE FW PIPE BREAK EVENT …......................................2

8. COMPUTER DECK FOR VACUUM VESSEL CRYOSTAT FAILURE WATER AIR INGRESS

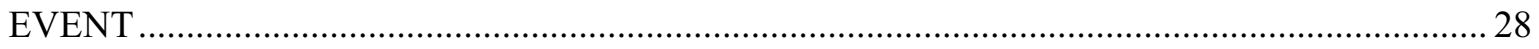

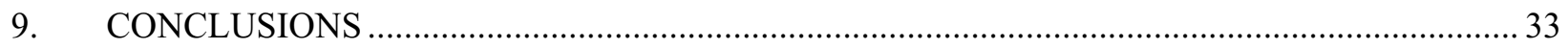

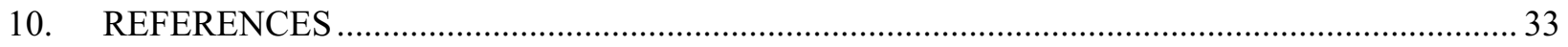

\section{FIGURES}

Figure 2-1 FW/BLK Model (failed loop) in Coolant Leak Port Cell Normal Deck .................................. 5

Figure 2-2 FW/BLK Model (two intact loops) in Coolant Leak Port Cell Normal Deck......................... 6

Figure 2-3 VV and Suppression System Model in Coolant Leak Port Cell Normal Deck ...................... 7

Figure 2-4 Confinement and Vent-Detritiation Model in Coolant Leak Port Cell Normal Deck .............. 8

Figure 2-5 Simplified VVPHTS Model (both loops) in Coolant Leak Port Cell Normal Deck ................ 8

Figure 3-1 FW/BLK Model (failed loop) in Coolant Leak Port Cell Bake Deck ................................. 11

Figure 3-2 Simplified Divertor Loop Model in Coolant Leak Port Cell Bake Deck .............................. 11

Figure 4-1 FW/BLK Model (failed loop) in Cryostat Water Ingress Deck .......................................... 14

Figure 4-2 FW/BLK Model (two intact loops) in Cryostat Water Ingress Deck .................................. 14 
Figure 4-3 VV and Suppression System Model in Cryostat Water Ingress Deck.

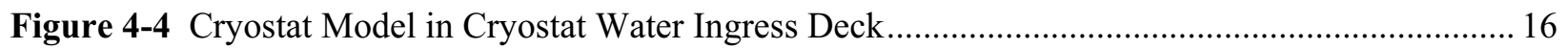

Figure 4-5 Confinement and Vent-Detritiation Model in Cryostat Water Ingress Deck ........................ 16

Figure 5-1 FW/BLK Model (three intact loops) in Large Divertor Ex-Vessel Pipe Break Deck............. 18

Figure 5-2 VV and Suppression System Model in Large Divertor Ex-Vessel Pipe Break Deck ............. 19

Figure 5-3 Confinement and Vent-Detritiation Model in Large Divertor Ex-Vessel Pipe Break Deck ... 20

Figure 5-4 Divertor Heat Transport Model in Large Divertor Ex-Vessel Pipe Break Deck.................... 20

Figure 6-1 FW/BLK Model (one intact loop) in Loss of Vacuum Dry-Bypass Deck ............................ 22

Figure 6-2 FW/BLK Model (two intact loops) in Loss of Vacuum Dry-Bypass Deck ......................... 23

Figure 6-3 Confinement and Vent-Detritiation Model in Loss of Vacuum Dry-Bypass Deck................. 23

Figure 7-1 FW/BLK Model (three failed loops) in Multiple FW Pipe Break Deck ............................... 25

Figure 7-2 VV and Suppression System Model in Multiple FW Pipe Break Deck ...............................26

Figure 7-3 Confinement and Vent-Detritiation Model in Multiple FW Pipe Break Deck...................... 27

Figure 7-4 Divertor Loop Model (one loop) in Multiple FW Pipe Break Deck ................................... 27

Figure 8-1 FW/BLK Model (failed loop) in VV Cryostat Failure Water Air Ingress Deck .....................29

Figure 8-2 FW/BLK Model (two intact loops) in VV Cryostat Failure Water Air Ingress Deck............ 29

Figure 8-3 VV and Suppression System Model in VV Cryostat Failure Water Air Ingress Deck ........... 31

Figure 8-4 Cryostat Model in VV Cryostat Failure Water Air Ingress Deck ....................................... 32

Figure 8-5 Confinement and Vent-Detritiation Model in VV Cryostat Failure Water Air Ingress Deck. 32 


\section{Verification of MELCOR Input Decks Used in ITER RPrS Analyses}

\section{INTRODUCTION}

This report as part of ITER Task Agreement [Sau07] documents the verification of the MELCOR Input Computer Decks used in performing the required safety analyses to be presented in International Thermonuclear Experimental Reactor's (ITER's) Preliminary Safety Report (Rapport Préliminaire de Sûreté, RPrS). The RPrS is a document which must be approved by the French Nuclear Safety Authority (Autorité de Sûreté Nucléaire, ANS) before a construction permit can be granted to ITER. As part of the RPrS a select set of postulated design base accidents (DBA) and beyond design base accidents (BDBA) [AAS07], had to be run in order to show that the ITER design can withstand these accidents without violating ITER's site boundary dose limits. The originally, seven MELCOR input decks for these accidents were loaded on to the ITER document management (IDM) system in July of 2007 by the ITER International Organization (IO). The verification of these seven decks is presented in this report.

All seven of the decks being validated consist of a number of sub-models such as the: (1) FW/BLK Coolant Loop Model , (2) VV and Suppression System Model, (3) Cryostat Model, (4) Confinement and Vent-Detritiation System Model, (5) VV-PHTS Model, and (6) Divertor Heat Transport Model. Ideally, all of the decks should have been constructed from a common set of sub-models built specifically for the accidents to be presented in the RPrS. However, due to a compressed work schedule, the decks loaded on IDM were decks that had been used previously for parametric studies of these accidents. This meant that each deck had to be treated as an entirely separate deck, independent of what was found in the other deck.

The verification process for each computer deck consisted of a number of tasks, which are as follows:

1. Verify that the each control volumes (CV) used to represent an ITER component volumes such as the plasma chamber, suppression system piping, etc, has a volumes vs. height table that is consistent with that given in [SADL07].

2. Verify that the each flow path (FP) connecting the CVs in a given sub-model have the correct lengths, flow areas, and hydraulic diameters as determined from information given in [SADL07].

3. Verify that each heat structure used in a given sub-model (walls, pipes and materials) represents the structure as described in [SADL07].

4. Ensure that the opening of valves used to simulate breaks in the piping and walls occur at the correct time or pressure differential. Make sure that the break area and location of these simulated breaks are consistent with those described in the [AAS07].

5. Ensure that the control logic used to simulate leaks in various ITER confinement building rooms is programmed correctly to give leak rates as specified in [SADL07] and [AAS07].

To facilitate this process at the INL, the decks were loaded into the SNAP input deck building utility [SNAP07]. This utility contains a Graphical User Interface (GUI) that not only allowed for visualizing the structure of the model but easy access to pertinent model information, such as volumes, 
areas, lengths, etc. Once an error was identified in a particular deck, this error was reported to the ITER IO Safety Organization, and the decks were revised and a new version of the deck placed on IDM by the ITER IO.

It should be noted that other members of the ITER team were also submitting corrections to the input decks. Those corrections may or may not be included in the list presented in this report, however after viewing the latest version of the computer decks dated November 27, 2007 (11/27/07) it appears that all major discrepancies in the original decks have been corrected.

The following sections of this report address the validation of each of the seven MELCOR input decks examined by the US under this Task Agreement. The final sections present some conclusions drawn from this effort.

\section{COMPUTER DECK FOR THE COOLANT LEAK IN THE PORT CELL NORMAL EVENT}

The MELCOR computer deck representing this accident (see [AAS07] for description of this accident) consists of five sub-models. The sub-models are: (1) FW/BLK Coolant Loop Model (one loop with break - Figure 2.1), (2) FW/BLK Cooling Loop Model (two intact loops - Figure 2.2), (3) VV and Suppression System Model (Figure 2.3), (4) Confinement and Vent-Detritiation System Model (Figure 2.4), and (5) Simplified VVPHTS Model (both loops - Figure 2.5).

The items listed below were identified as needing corrected in the original deck in order to comply with both [SADL07] and the [AAS007] documents. The original deck placed on the IDM system was identified as Coolant_Leak_PortCellNormal_276W3F_1_0.inp. The final version of the deck as of 11/27/07, identified as Coolant_Leak_Port ITER-D_276 $\bar{W} 3 F \_v 2 \_4$.inp was compared to the original deck to ensure that all of these corrections were properly made to the deck. These corrections are:

1) The flow area of FP 1 was found to be incorrect in the original deck. It was change from $1.18 \mathrm{~m}^{2}$ to $0.59 \mathrm{~m}^{2}$ which is the flow area corresponding to one FW/BLK coolant loop [Topilski07]. The hydraulic diameter was also changed from $0.122 \mathrm{~m}$ to $0.87 \mathrm{~m}$ which corresponds to the one loop flow area $\left(0.59 \mathrm{~m}^{2}\right)$ between pressurizer \#1 (CV028) and pressurizer \#2 (CV018).

2) The loss coefficient in FP 2 was changed from 8.0 to 11.5 . (Identified by other members of the ITER team. Now agrees with what is in the port cell baking deck. )

3) The loss coefficient in FP 16 was changed from 8.0 to 8.9. (Identified by other members of the ITER team. Now agrees with what is in the port cell baking deck.)

4) The loss coefficient in FP 18 was changed from 7.5 to 13.5. (Identified by other members of the ITER team. Now agrees with what is in the port cell baking deck.)

5) The lengths of FP f1007s1, f1009s1, fl013s2, f1021s2 (Figure 2.1) and FP f1905s2, f1906s1, f1909s 1, f1913s2 (Figure 2.2) were determined to be incorrect in the original deck. Their lengths were decreased from $66 \mathrm{~m}$ to $33 \mathrm{~m}$. Because of the reduction in lengths, the total length of fl007, fl009, fl013, f1021, f1905, f1906, fl909, and f1913 are 45.3m, $46.2 \mathrm{~m}, 49.1 \mathrm{~m}$, $45.3 \mathrm{~m}, 45.3 \mathrm{~m}, 45.3 \mathrm{~m}, 46.2 \mathrm{~m}, 49.1 \mathrm{~m}$ respectively [Topilski07]. 
6) The hydraulic diameter of FP 908 (Figure 2.2) was determined to be incorrect in the original deck. It was changed from $0.122 \mathrm{~m}$ to $0.87 \mathrm{~m}$.

7) Heat structures 912, 914, 924, 928, 930, 926, 932, 935, 936, 937, 938, and 939 were missing from the original deck but have since been added to the FW/BLK coolant loop (two intact loops) sub-model of the latest deck.

8) As the final version of the deck now stands (base case), the pump head vs. time table (tf926) for the intact FW/BLK PHTS trips at 1000 seconds, coasts down to zero head by 1030 seconds and remains off for 32 hours. The analyst using this deck must be aware that he/she must modify this table depending on the specific accident case being analyzed i.e. class III power is assumed to come on at different times for the various parametric cases considered.

9) CF906 (control function 906) which controls when the FW/BLK heat exchanger for the two FW/BLK intact coolant loops is turn off was changed from $1.32 \mathrm{E}+05$ seconds to $1.0 \mathrm{E}+06$ seconds. However, there was no criterion identified in the [AAS07] for determining when the HX should be shut off.

10) In the plasma chamber a $\mathrm{H}_{2}$ source from the cryopumps and Be dust (Divertor hot spots) reaction with steam were missing from the original deck. The two sources were added to the plasma chamber (CV100) using table functions tf302 and tf303. (Identified by other members of the ITER team)

11) CF142 was changed. The original deck had a trip delay of 30 seconds associated with the valve (controlled by CF145) located in FP 5 and FP 6 (Figure 2.1). This trip delay was changed from 30 seconds to 60 seconds [AAS07].

12) The break area corresponding to FP 37 which connects the inboard outlet manifold (CV009) with the port cell (CV153) should be $0.006842 \mathrm{~m}^{2}$ and the corresponding hydraulic diameter should be $0.066 \mathrm{~m}$ [AAS07].The latest deck version (11/27/07) still has a flow area of $0.02520 \mathrm{~m}^{2}$ and a corresponding hydraulic diameter of $0.126 \mathrm{~m}$.

13) The volume of the TCWS vault (CV133 - Figure 2.4) in the original deck did not agree with the value listed in [SADL07]. The volume in the latest deck was changed from $22970 \mathrm{~m}^{3}$ to $23223 \mathrm{~m}^{3}$ to agree with the data in [SADL07].

14) The volume of the pipe chases and shafts (CV134 - Figure 2.4) in the original deck did not agree with the value listed in [SADL07]. The volume in the latest deck was changed from $16275 \mathrm{~m}^{3}$ to $14784 \mathrm{~m}^{3}$ to agree with the data in [SADL07].

15) The surface area of heat structure hs136 (TCWS walls) in the original deck did not agree with the value listed in [SADL07]. The surface area in the latest deck was changed from $3400 \mathrm{~m}^{2}$ to $4680 \mathrm{~m}^{2}$ to agree with the data in [SADL07].

16) The surface area of heat structure hs137 (TCWS ceiling) in the original deck did not agree with the value listed in [SADL07]. The surface area in the latest deck was changed from $2300 \mathrm{~m}^{2}$ to $1400 \mathrm{~m}^{2}$ to agree with the data in [SADL07].

17) The surface area of heat structure hs 138 (TCWS floor) in the original deck did not agree with the value listed in [SADL07]. The surface area in the latest deck was changed from $2300 \mathrm{~m}^{2}$ to $1400 \mathrm{~m}^{2}$ to agree with the data in [SADL07]. 
18) The surface area of heat structure hs133 (Pipe chase walls) in the original deck did not agree with the value listed in [SADL07]. The surface area in the latest deck was changed from $5600 \mathrm{~m}^{2}$ to $5100 \mathrm{~m}^{2}$ to agree with the data in [SADL07].

19) The surface area of heat structure hs134 (Pipe chase ceiling) in the original deck did not agree with the value listed in [SADL07]. The surface area in the latest deck was changed from $450 \mathrm{~m}^{2}$ to $1900 \mathrm{~m}^{2}$ to agree with the data in [SADL07].

20) The surface area of heat structure hs 135 (Pipe chase floor) in the original deck did not agree with the value listed in [SADL07]. The surface area in the latest deck was changed from 450 $\mathrm{m}^{2}$ to $900 \mathrm{~m}^{2}$,however, it should have been changed to $970 \mathrm{~m}^{2}$ to agree with the data in [SADL07].

21) The surface area of heat structure hs 147 (Gallery ceiling) in the original deck did not agree with the value listed in [SADL07]. The surface area in the latest deck was changed from $2700 \mathrm{~m}^{2}$ to $4000 \mathrm{~m}^{2}$ to agree with the data in [SADL07].

22) The surface area of heat structure hs148 (Gallery floor) in the original deck did not agree with the value listed in [SADL07]. The surface area in the latest deck was changed from $2700 \mathrm{~m}^{2}$ to $4000 \mathrm{~m}^{2}$ to agree with the data in [SADL07].

23) The surface area of heat structure hs145 (Port cell walls) in the original deck did not agree with the value listed in [SADL07]. The surface area in the latest deck was changed from 140 $\mathrm{m}^{2}$ to $150 \mathrm{~m}^{2}$ to agree with the data in [SADL07].

24) The timing on the opening of the valve located in FP 209 (Figure 2.4) was change from 4600 $\mathrm{sec}$ to $1030 \mathrm{sec}$ (CF225, Class III power). The opening time of this valve is a function of the parameter cases being run.

25) The timing on the opening of the valve located in FP 266 (Figure 2.4) was changed from $4600 \mathrm{sec}$ to $1030 \mathrm{sec}$ (CF236, Class III power). The opening time of this valve is a function of the parameter cases being run.

26) The timing of the opening of the valve located in FP 217 was changed from $4600 \mathrm{sec}$ to 1030 sec (CF286, Class III power). The opening time of this valve is a function of the parameter cases being run.

27) The original deck had no in-vessel break from the FW/BLK to the plasma chamber as listed in AAS. FP 36 (Figure 2.1) was added to the latest deck to simulate the in-vessel break.

28) Jet impingement volume (CV450), FP from jet impingement volume to plasma chamber (FP 451 and 452 - Figure 2.3), heat structure representing the jet impingement target (HS450), and supporting control functions (CF450, CF451, CF452, CF453 and CF454) were added to the model since all break flows into the plasma chamber are assumed to impinge on the plasma chamber wall.

29) The VV nuclear heating vs. timetable (tf700) needed to be updated to reflect the latest steady state value (6.5 MW) given in [SADL07]. The 11/27/07 deck now has the updated value of $6.5 \mathrm{MW}$. 
30) [SADL07] (Table 3_5.1-2) indicates that the sum of the lengths of FP 107, 109, 111, 113, 115 should be $94 \mathrm{~m}$. The 11/27/07 deck has the sum of the above flow paths as $49 \mathrm{~m}$. In addition, the minimum flow area listed in [SADL07] for the above flow paths is $1.21 \mathrm{~m}^{2}$ not $1.15 \mathrm{~m}^{2}$.

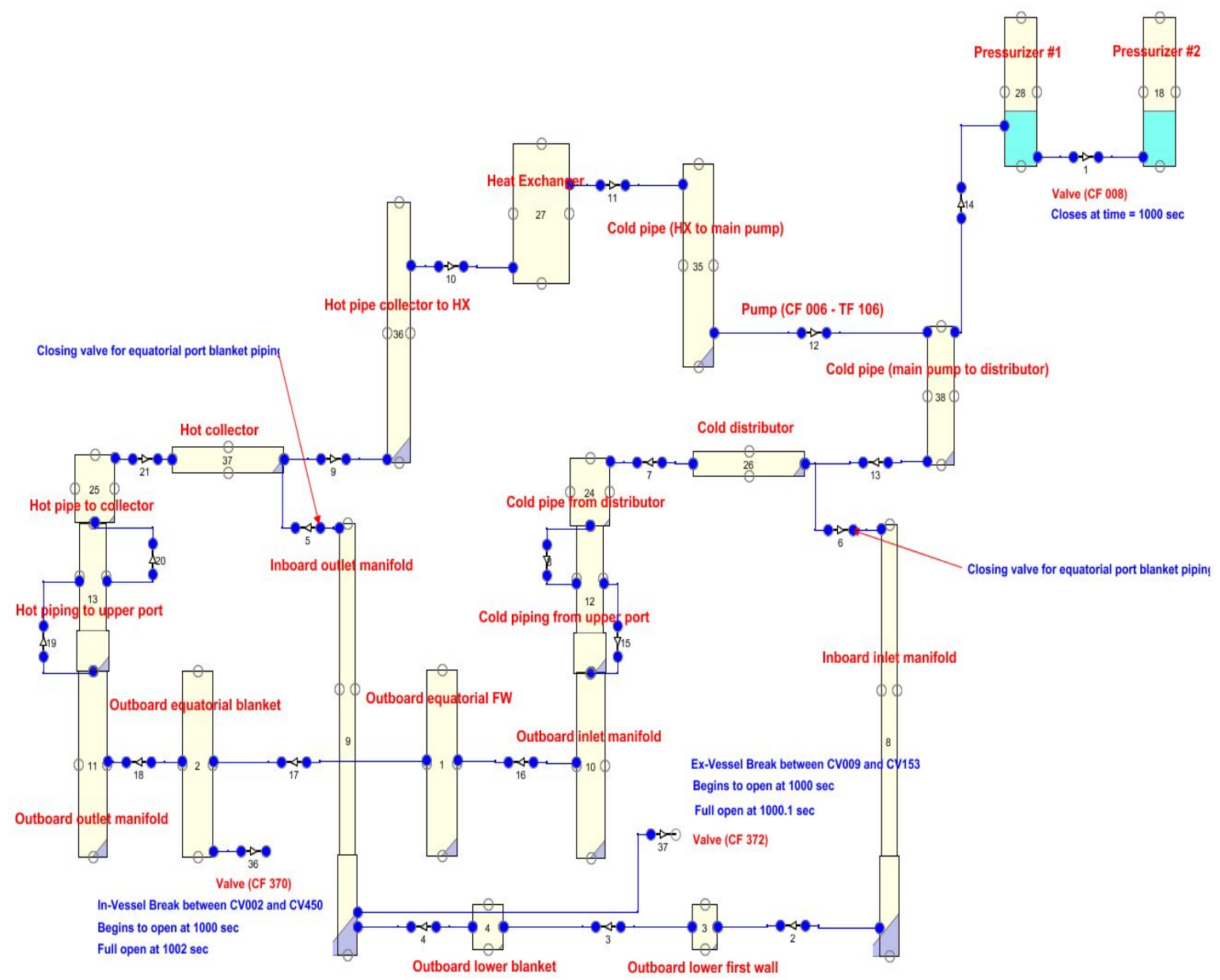

Figure 2-1 FW/BLK Model (failed loop) in Coolant Leak Port Cell Normal Deck 


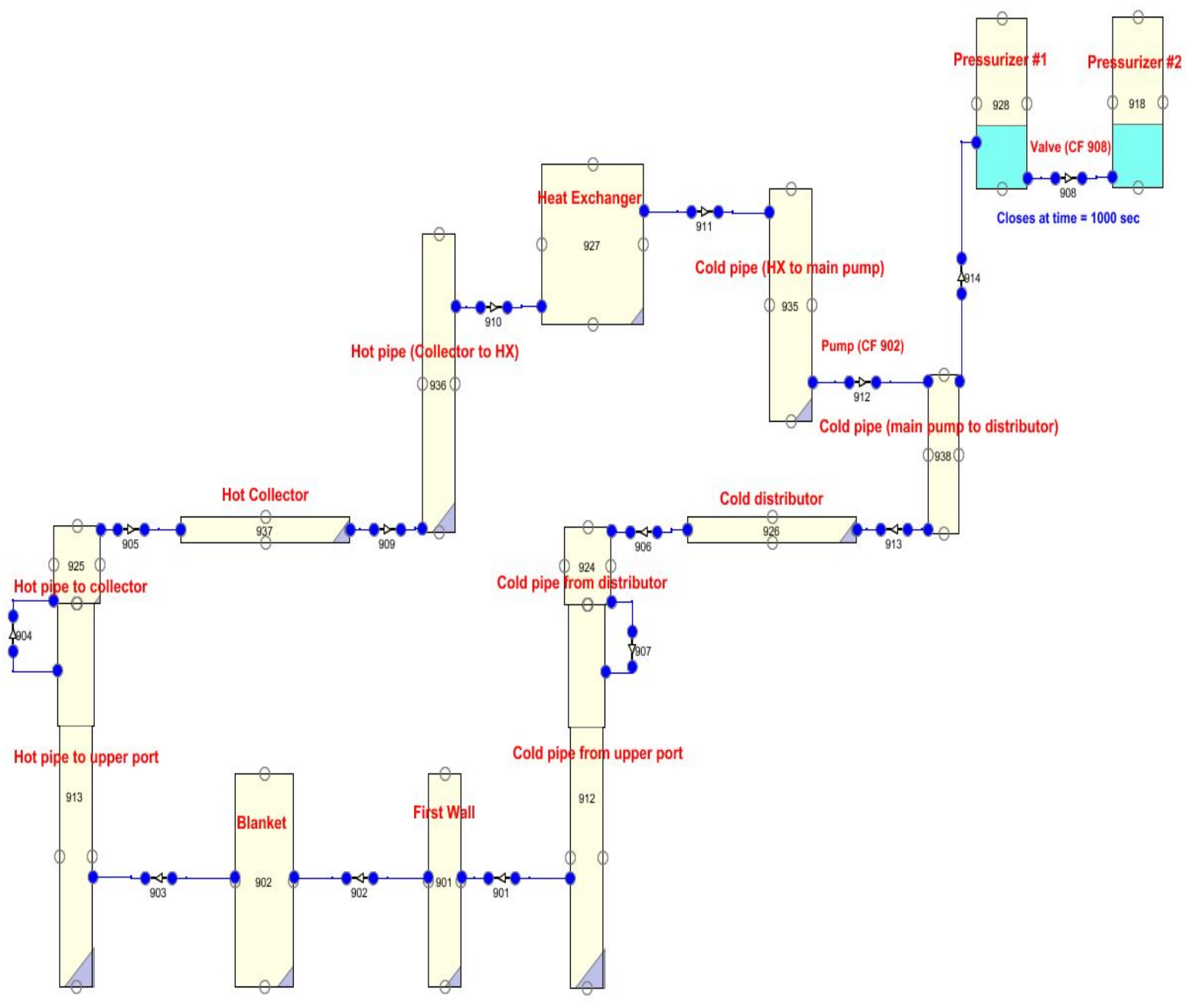

Figure 2-2 FW/BLK Model (two intact loops) in Coolant Leak Port Cell Normal Deck 


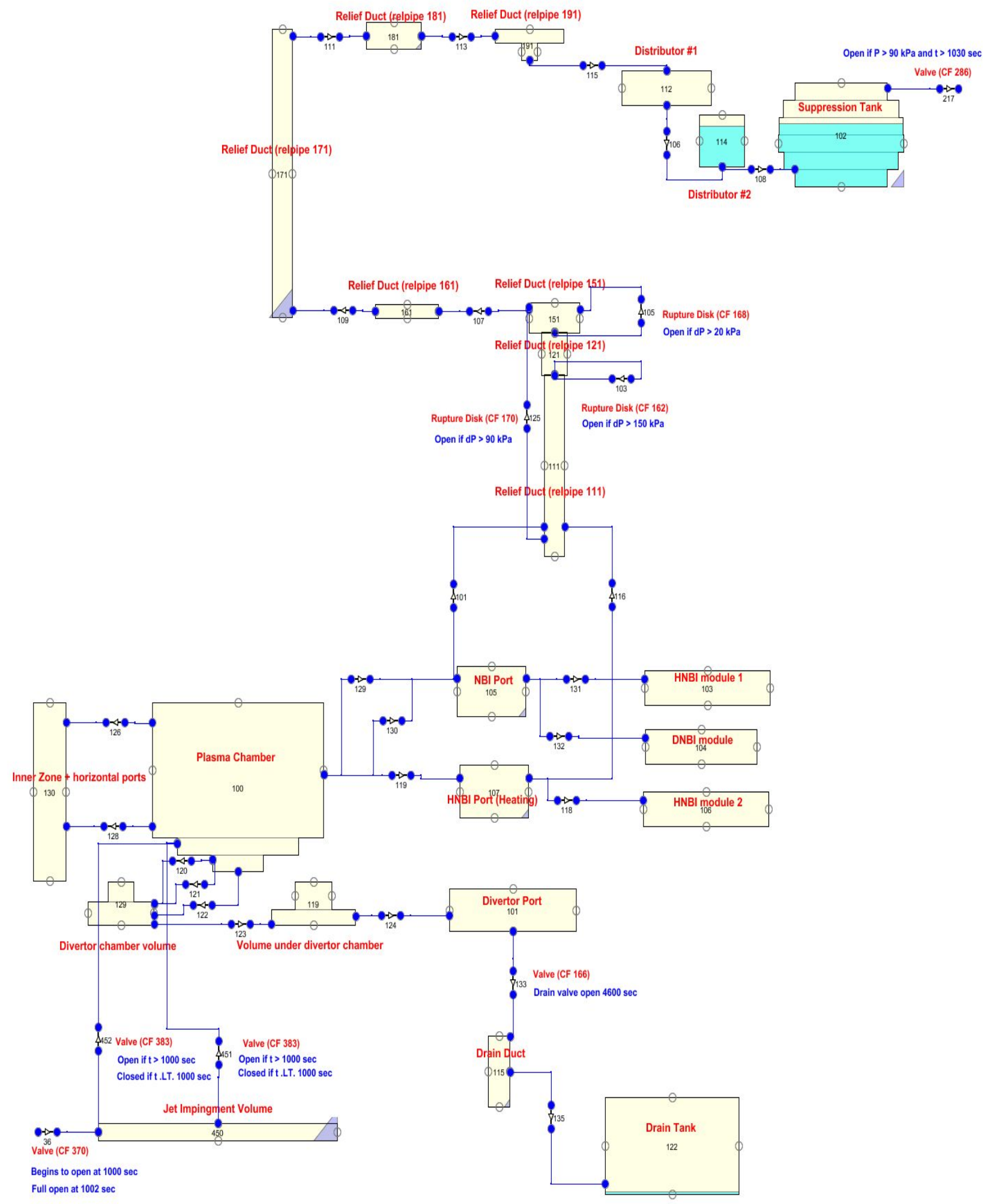

Figure 2-3 VV and Suppression System Model in Coolant Leak Port Cell Normal Deck 


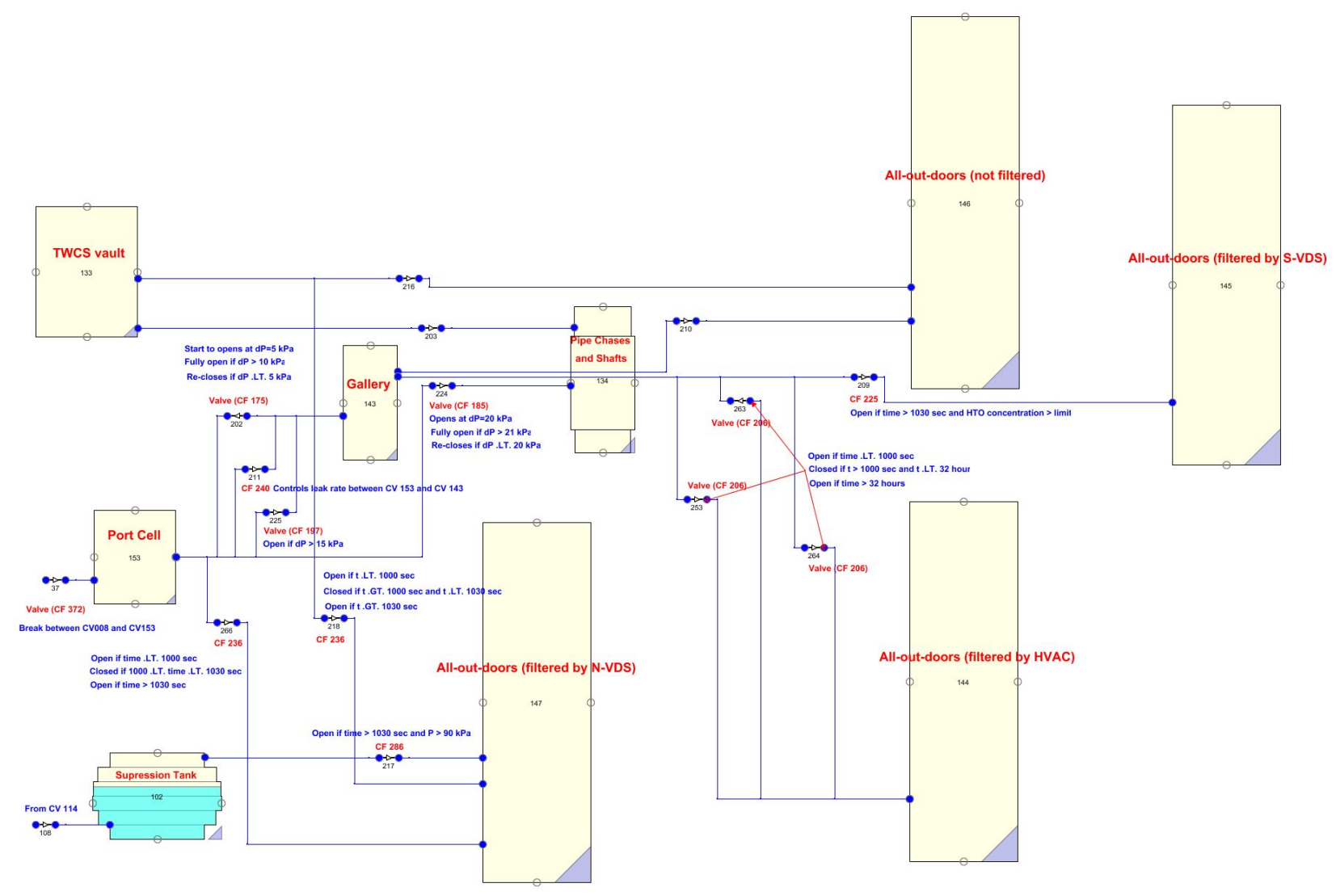

Figure 2-4 Confinement and Vent-Detritiation Model in Coolant Leak Port Cell Normal Deck

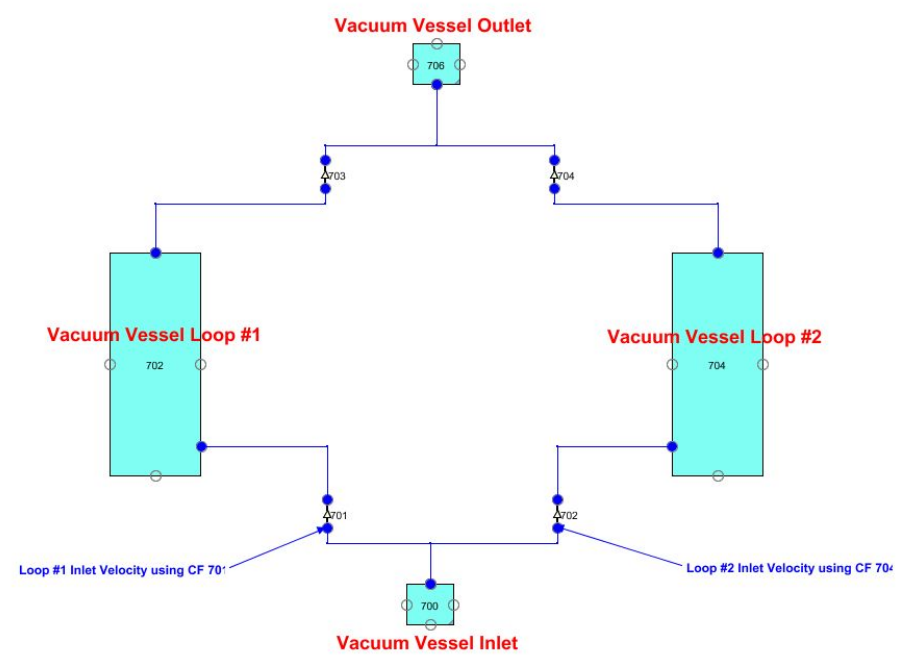

Figure 2-5 Simplified VVPHTS Model (both loops) in Coolant Leak Port Cell Normal Deck 


\section{COMPUTER DECK FOR THE COOLANT LEAK IN THE PORT CELL BAKING EVENT}

The computer deck used to represent this accident is essentially the same as used for the port cell nominal accident. As discussed in the introduction, even though the sub-models of this deck are similar to those of Section 2, because the sub-models, for example the FW/BLK PHTS, did not come from a common source, any errors associated with one deck may or may not have been propagated correctly throughout all of the decks. In addition, there was no process in place to ensure that errors fixed in a common model in one deck propagated to all decks. Therefore, all decks had to be checked as if they were entirely independent decks.

The MELCOR computer deck representing this accident (see [AAS07] for description of this accident) consists of six sub-models. The sub-models are: (1) FW/BLK Coolant Loop Model (one loop with break - Figure 3.1), (2) FW/BLK Cooling Loop Model (two intact loops - Figure 2.2), (3) VV and Suppression System Model (Figure 2.3), (4) Confinement and Vent-Detritiation System Model (Figure 2.4), (5) Simplified VVPHTS Model (both loops - Figure 2.5) and (6) Simplified Divertor Heat Transport Model (Figure 3.2). Four of the Figures listed above are the same Figures as presented in Section 2.

The items listed below were identified as requiring corrections in the original deck in order to be in compliance with both the [SADL07] and the [AAS07] documents. The original deck placed on the IDM system is identified as Coolant_LeakPortCellBaking_276W2X_1_0.inp. The final version of the deck as of 11/27/07, identified as Coolant_LeakPortC_ITER_D_276W2X_v2_4.inp was compared to the original deck to ensure that all the corrections were properly made to this deck.

The noted corrections are:

1) See item $1-$ section 2.

2) See item 5 - section 2 .

3) The heat structure node number on control function CF01211 was changed from hstemp.0000105 to hs-temp.0000106. Node 06 (not node 05) is the exterior node of heat structure 00001 which faces node 01 of hs-temp.00004.

4) The heat structure node number on control function CF03011 was changed from hstemp.0000205 to hs-temp.0000206. Node 06 (not node 05) is the exterior node of heat structure 00002 which faces node 01 of hs-temp.00006.

5) The hydraulic diameter of FP 901 (Figure 3.2) was determined to be incorrect in the original deck. It was changed from $0.122 \mathrm{~m}$ to $0.87 \mathrm{~m}$.

6) The heat structure node number on control function CF91211 was changed from hstemp.0090105 to hs-temp.0090106. Node 06 (not node 05) is the exterior node of heat structure 00901 which faces node 01 of hs-temp.00904.

7) See item $8-$ section 2 .

8) See item $9-$ section 2 . 
9) See item $11-$ section 2.

10) See item 13 - section 2.

11) See item $14-$ section 2.

12) See item 15 - section 2.

13) See item 16 - section 2.

14) See item 17 - section 2.

15) See item 18 - section 2.

16) See item 19 - section 2.

17) See item 20 - section 2.

18) See item 21 - section 2.

19) See item $22-$ section 2.

20) See item 23 - section 2.

21) See item 24 - section 2.

22) See item $25-$ section 2.

23) See item $26-$ section 2.

24) The break area corresponding to FP 37 which connects the inboard outlet manifold (CV009) with the port cell (CV153) should be $0.006842 \mathrm{~m}^{2}$ and the corresponding hydraulic diameter should be $0.066 \mathrm{~m}$ [AAS07]. The deck Coolant_LeakPortC_ITER_D_276W2X_v2_4.inp still has a flow area of $0.02520 \mathrm{~m}^{2}$ and a corresponding hydraulic diameter of $0.126 \mathrm{~m}$.

25) See item $30-$ section 2. 


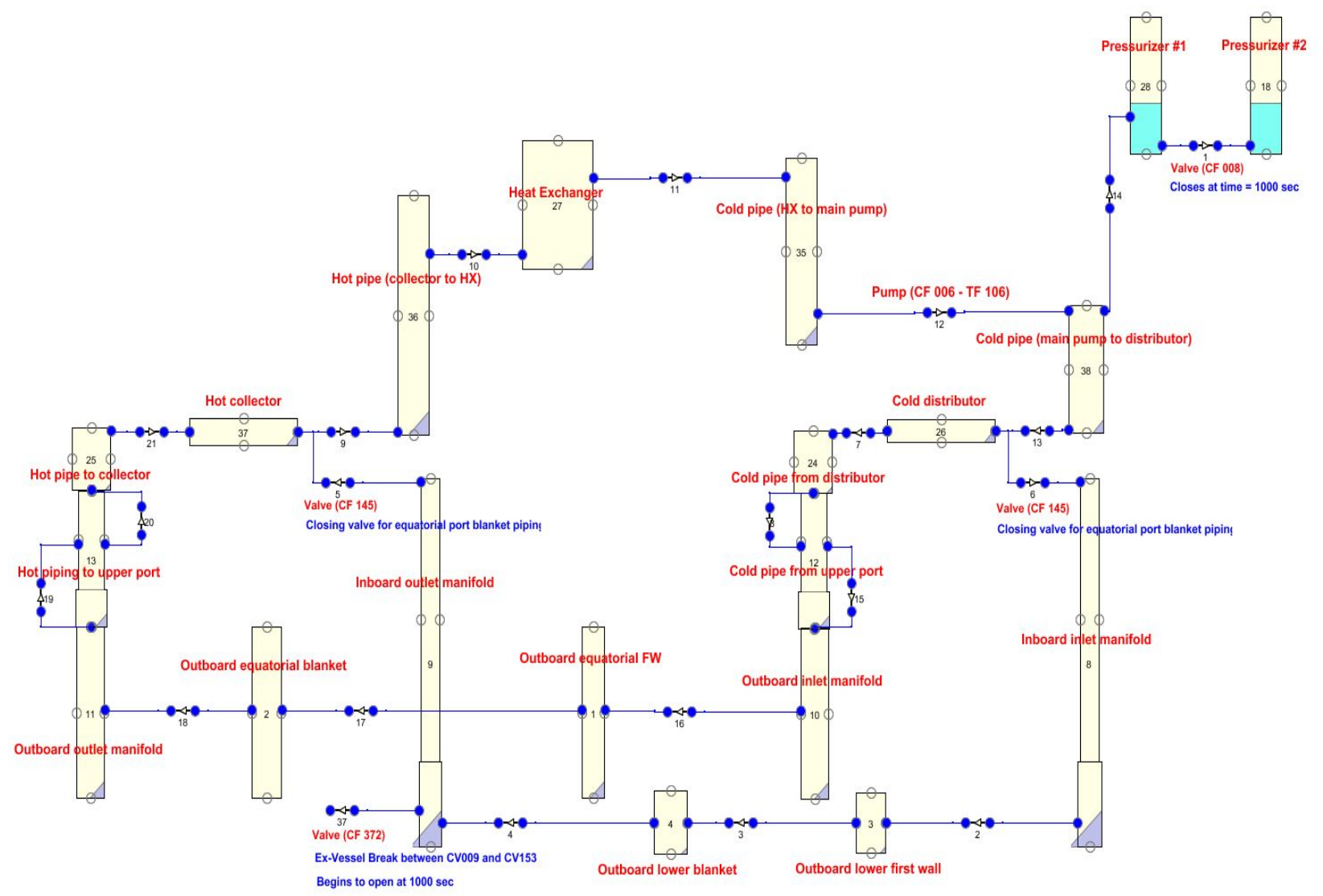

Figure 3-1 FW/BLK Model (failed loop) in Coolant Leak Port Cell Bake Deck

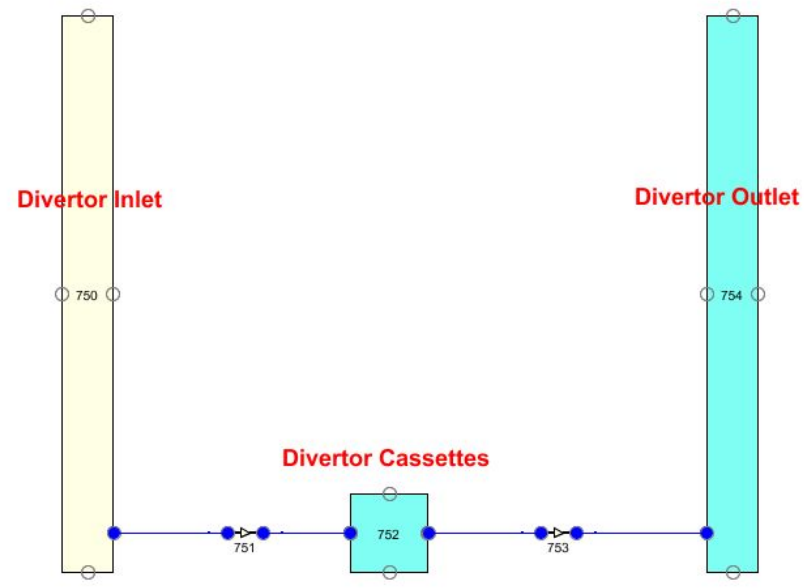

Figure 3-2 Simplified Divertor Loop Model in Coolant Leak Port Cell Bake Deck 


\section{COMPUTER DECK FOR CRYOSTAT WATER INGRESS EVENT}

The MELCOR computer deck representing this accident (see [AAS07] for description of this accident) consists of seven sub-models. The sub-models are: (1) FW/BLK Coolant Loop Model (one loop with break - Figure 4.1), (2) FW/BLK Cooling Loop Model (two intact loops - Figure 4.2), (3) VV and Suppression System Model (Figure 4.3), (4) Cryostat Model (Figure 4.4), (5) Confinement and VentDetritiation System Model (Figure 4.5), (6) Simplified VVPHTS Model (both loops - Figure 2.5), and (7) Simplified Divertor Heat Transport Model (Figure 3.2). The simplified VVPHTS and the simplified divertor heat transport models are the same as presented in Section 2 and Section 3 thus, will not be redrawing in this section.

The items listed below were identified as needing corrected in the original deck in order to be in compliance with both the Safety Analysis Data List Version 5.2 [SADL07] and the Accident Analysis Specifications Version 5.2.5 [AAS07] documents. The original deck placed on the ITER IDM system is identified as CryostatWaterAir_Ingress_276UVK_1_0.inp. The final version of the deck as of 11/27/07, identified as CryostatWaterHeIn_ITER_D_276UVKK_v3_4.inp was then compared to the original deck to ensure that all the corrections were properly made to this deck.

1) See item $1-$ section 2.

2) In the original deck the valve (Figure 4.1) located between pressurizer \#1 and pressurizer \#2 was programmed to remain open during the entire transient time. The valve should be programmed to isolate pressurizer \#1 from pressurizer \#2 at the time the accident is initiated (1000 seconds). This change now appears in the 11/27/07 deck.

3) The lengths of FP f1006s2, f1007s1, fl009s1, f1013s2 (Figure 4.1) and FP f1906s2, f1907s1, f1909s1, f1913s2 (Figure 4.2) were determined to be incorrect in the original deck. Their lengths were decreased from $66 \mathrm{~m}$ to $33 \mathrm{~m}$. Because of the reduction in segment lengths, the total lengths of f1006, f1007, f1009, f1013, f1906, f1907, f1909, and f1913 are 45.3m, $46.2 \mathrm{~m}$, $49.1 \mathrm{~m}, 45.3 \mathrm{~m}, 45.3 \mathrm{~m}, 46.2 \mathrm{~m}, 45.3 \mathrm{~m}, 49.1 \mathrm{~m}$ respectively [Topilski07]. These changes now appear in the 11/27/07 deck.

4) CF019 should be changed from cf01911 $0.0 \quad \mathbf{1 . 0}$ cfvalu.029 * radiate if $\mathbf{t}>\mathbf{1 0 0 0} \mathrm{s}$ to cf01911 $1.0 \quad 0.0$ cfvalu.029 * radiate if $\mathbf{t}>\mathbf{1 0 0 0} \mathrm{s}$. This change now appears in the 11/27/07 deck.

5) The FW/BLK loop pump head vs. time table (tf126) was changed to reflect that the pump head is zero at 1030 seconds [SADL07]. In the original deck, the pump head was set to zero at 1040 seconds.

6) In the original deck control function CF027 used table 127 as one of its inputs which was determined to be incorrect. The control function should use table 227. This change now appears in the 11/27/07 deck.

7) One of the cards associated with CV918 (Figure 4.2) input has a typo error. The card as given is cv94801 0 -1. The card should read as cv91801 $0-1$. This change now appears in the $11 / 27 / 07$ deck. 
8) Flow path f1901s 1 should use a hydraulic diameter of 0.87 not 0.122 as used in the original deck. This change now appears in the 11/27/07 deck.

9) CF919 should be changed from cf91911 $0.0 \quad \mathbf{1 . 0}$ cfvalu.028* radiate if $\mathbf{t}>\mathbf{1 0 0 0} \mathrm{s}$ to cf91911 $1.0 \quad 0.0$ cfvalu.028 * radiate if $\mathbf{t}>\mathbf{1 0 0 0} \mathrm{s}$. This change now appears in the 11/27/09 deck.

10) In the original deck, the initial atmosphere in the cryostat room (CV991 - Figure 4.4) was represented by helium. In the 11/27/07 deck, the atmosphere has been changed to nitrogen to represent air.

11) In the original deck the initial atmosphere in the space between the cryostat shield and outer cryostat wall (CV996) and the space between the VV (outer wall) and the thermal shield (CV997) was helium. In the 11/27/07 deck, the atmosphere has been changed to nitrogen to represent air.

12) The Gallery volume in the original deck was input as $66000 \mathrm{~m}^{3}$. [SADL07] list the volume of the Gallery as $66900 \mathrm{~m}^{3}$. The 11/27/07 deck now has the Gallery volume as $66900 \mathrm{~m}^{3}$.

13) In the original deck the break into the cryostat room was from CV701 (VVPHTS) to CV991 (cryostat room), however [AAS07] states that the break should be from the FW/BLK coolant loop to the cryostat room. The 11/27/07 deck now has the break from CV013 of the FW/BLK coolant loop to the cryostat room through FP 705 (Figure 4.4).

14) Since the break flow is now from CV013 to CV991 the detailed VVPHTS model is no longer required, the Simplified VVPHTS model (Figure 2.5) replaced the detailed VVPHTS model in the $11 / 27 / 07$ deck.

15) See item 29 - section 2.

16) The fraction of power from table tf700 applied to the VV heat structures hs00721, hs 00724 , hs00722, hs00741, hs00744, and hs00742 did not sum to 1.0 in the original deck. This has been corrected in the 11/27/07 deck.

17) [SADL07] (Table 3_5.1-2) indicates that the sum of the lengths of FP 107, 109, 111, 113, 115 should be $94 \mathrm{~m}$. The 11/27/07 deck has the sum of the above flow paths as $49 \mathrm{~m}$. In addition, the minimum flow area listed in [SADL07] for the above flow paths is $1.21 \mathrm{~m}^{2}$ not $1.15 \mathrm{~m}^{2}$. 


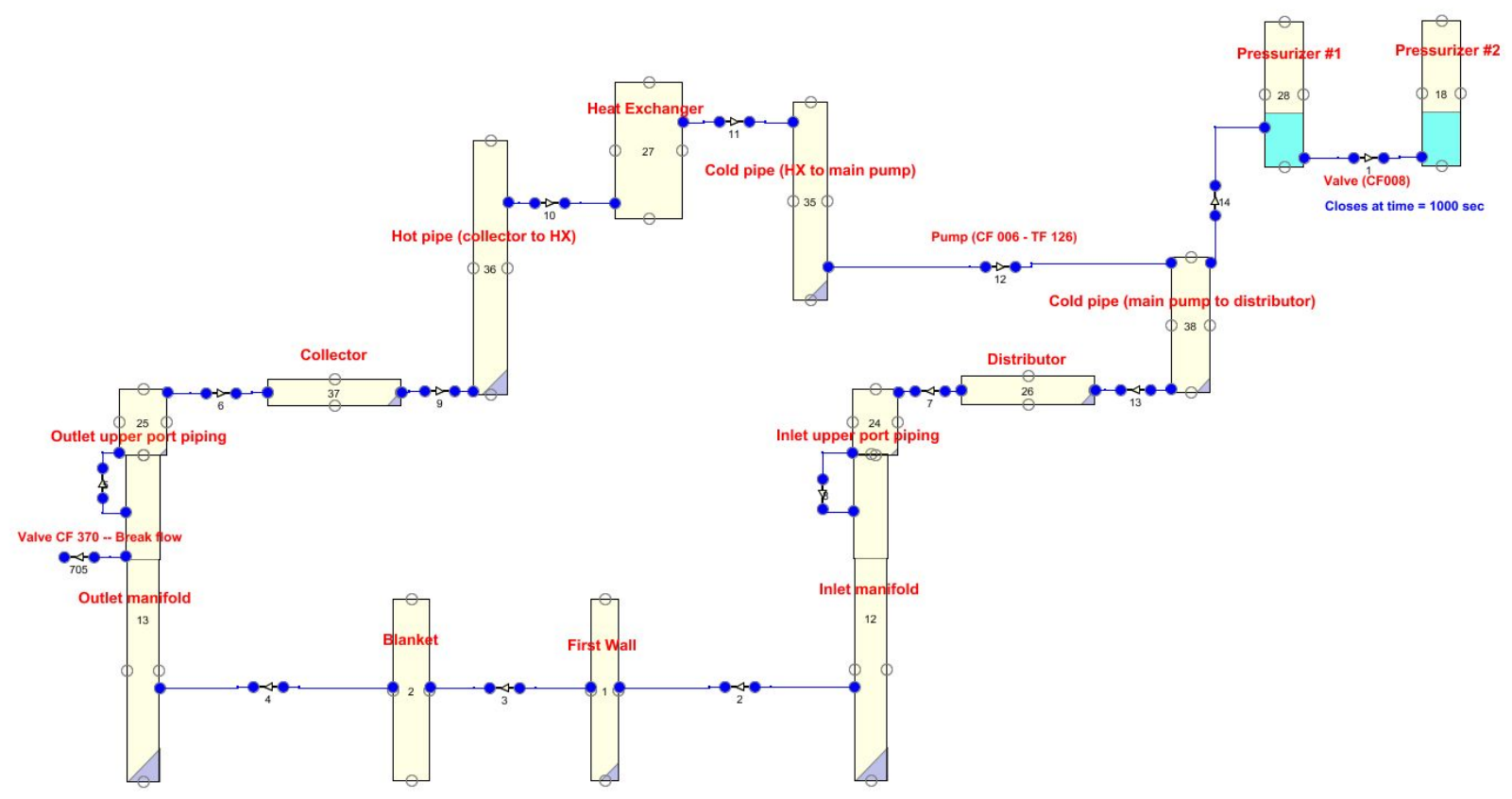

Figure 4-1 FW/BLK Model (failed loop) in Cryostat Water Ingress Deck

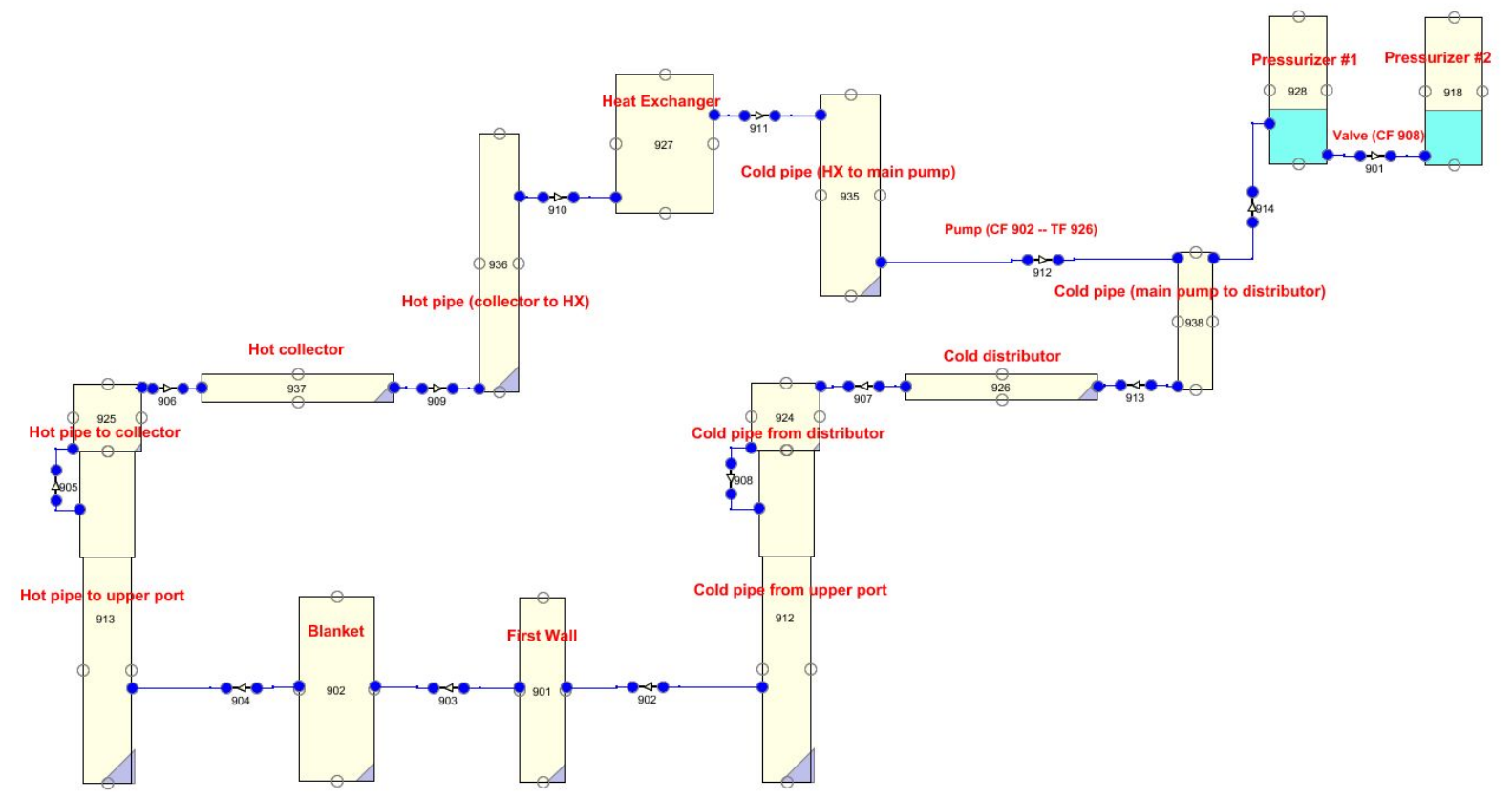

Figure 4-2 FW/BLK Model (two intact loops) in Cryostat Water Ingress Deck 


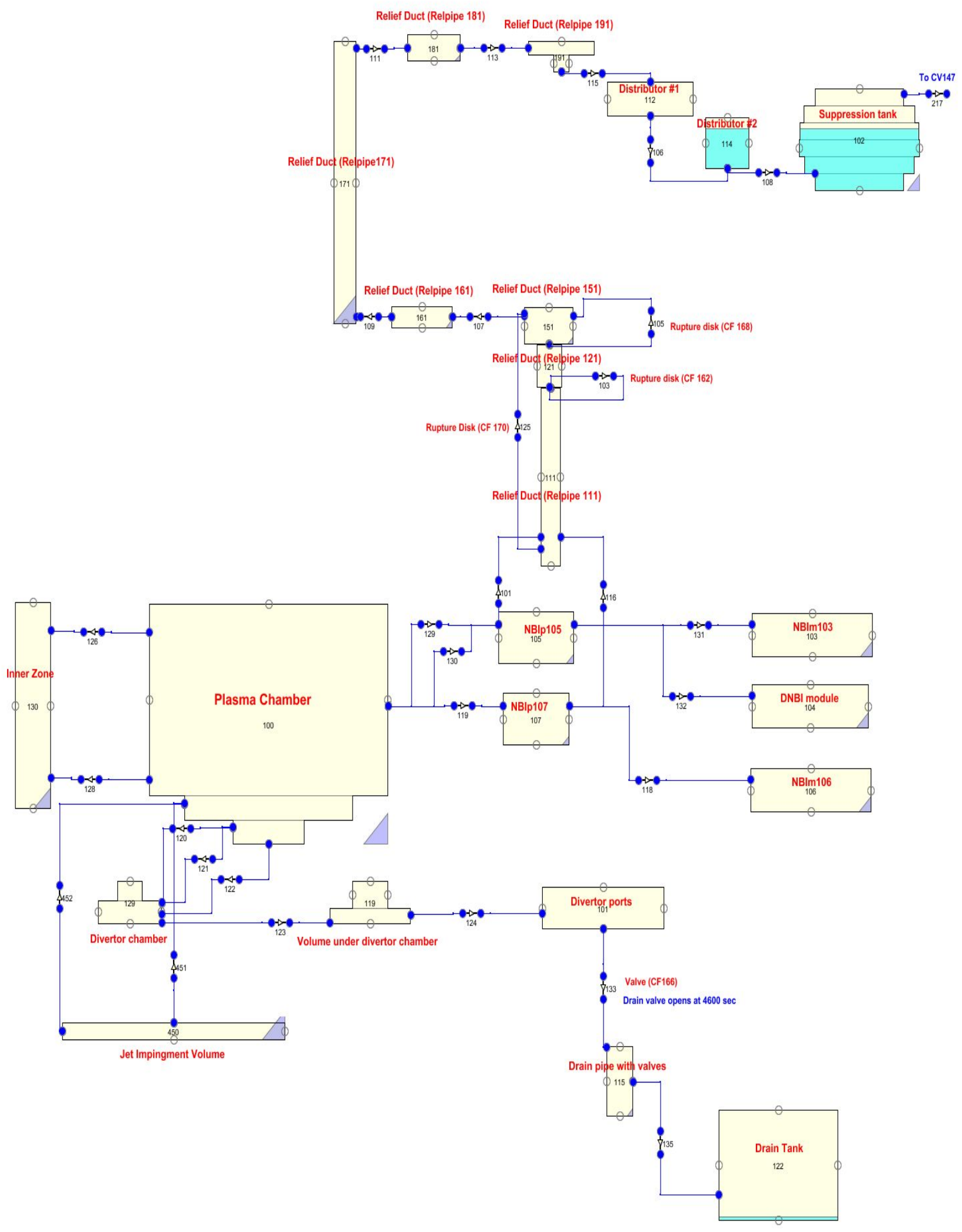

Figure 4-3 VV and Suppression System Model in Cryostat Water Ingress Deck 


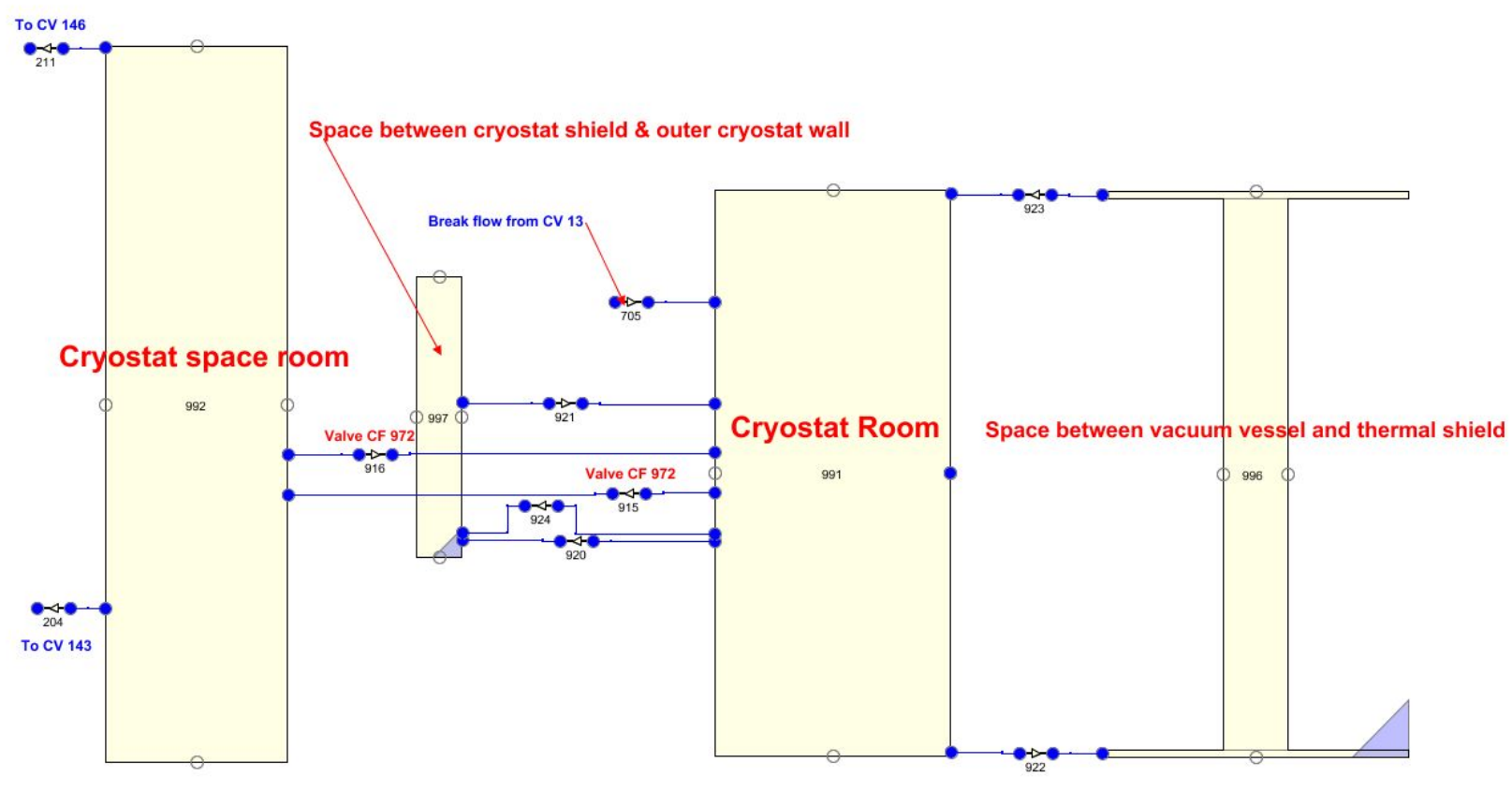

Figure 4-4 Cryostat Model in Cryostat Water Ingress Deck

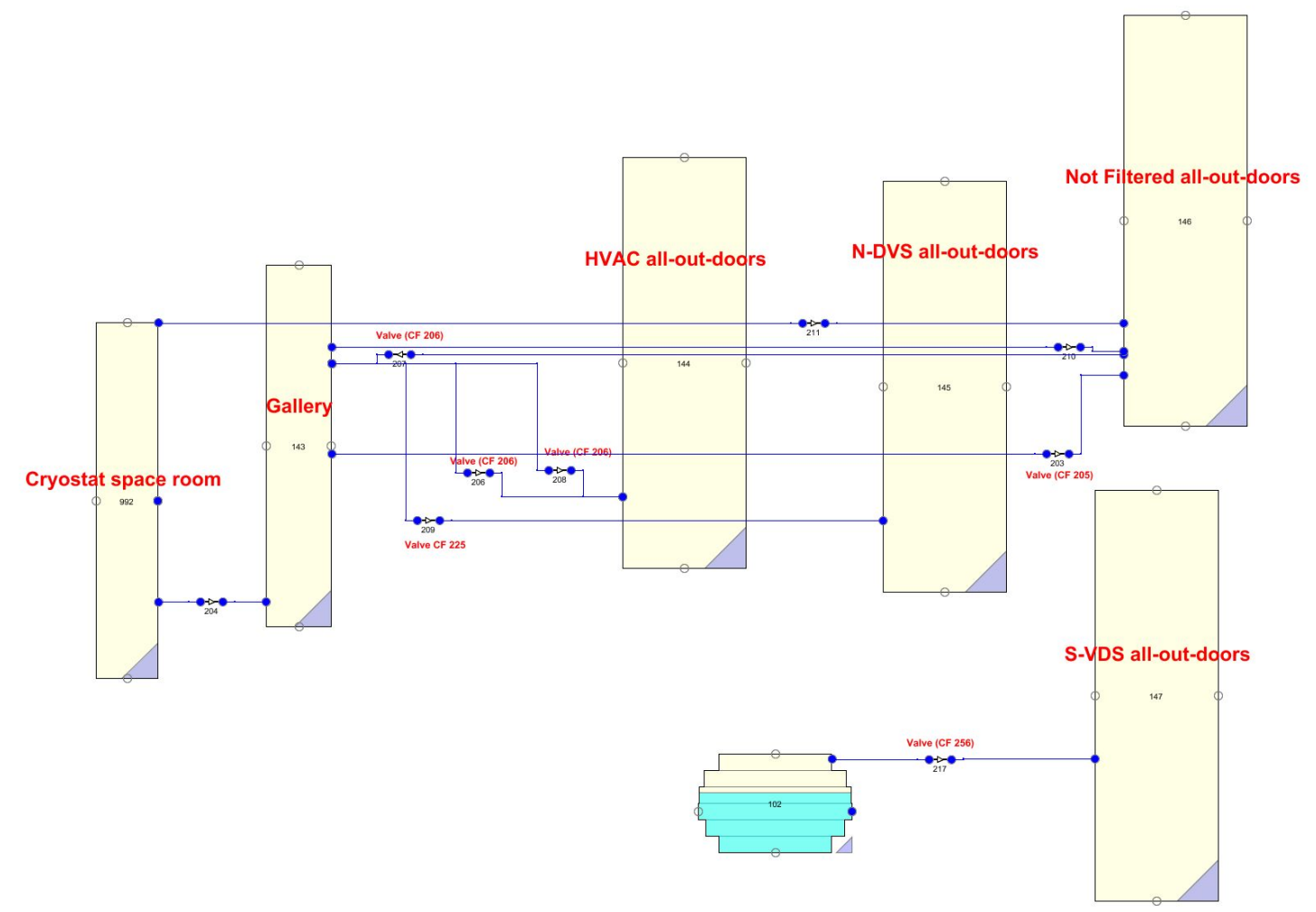

Figure 4-5 Confinement and Vent-Detritiation Model in Cryostat Water Ingress Deck 


\section{COMPUTER DECK FOR LARGE DIVERTOR EX-VESSEL PIPE BREAK EVENT}

The MELCOR computer deck representing this accident (see [AAS07] for description of this accident) consists of five sub-models. The sub-models are: (1) FW/BLK Coolant Loop Model (three intact loops - Figure 5.1), (2) VV and Suppression System Model (Figure 5.2), (3) Confinement and VentDetritiation System Model (Figure 5.3), (4) Divertor Heat Transport Model (Figure 5.4), (5) Simplified VVHTS Model (both loops - Figure 2.5)

The items listed below were identified as requiring correction in the original deck in order to be in compliance with both the [SADL07] and the [AAS07] documents. The original deck placed on the ITER IDM system is identified as LargeDVexvesselPipeBreak_276UW4_1_0.inp. The final version of the deck as of 11/27/07, identified as LargeDVexvesselPi_ITER_D_276UW4_v2_5.inp was compared to the original deck to ensure that all the corrections were properly made to this deck.

1) The hydraulic diameter of FP 418 (Figure 5.4) was found to be incorrect in the original deck. It was changed from $0.127 \mathrm{~m}$ to $0.87 \mathrm{~m}$ which corresponds to the one loop hydraulic diameter value between pressurizer \#1 (CV428) and pressurizer \#2 (CV418).

2) Flow path fl001s 1 should use a hydraulic diameter of $0.87 \mathrm{~m}$ not $0.122 \mathrm{~m}$ as used in the original deck. This change now appears in the 11/27/07 deck.

3) The lengths of FP f1006s2, f1007s1, fl009s 1 , and fl013s2 (Figure 5.1) were determined to be incorrect in the original deck. There lengths were decreased from $66 \mathrm{~m}$ to $33 \mathrm{~m}$. Because of the reduction in segment lengths, the total lengths of fl006, fl007, fl009, fl013 are $45.3 \mathrm{~m}$, $46.2 \mathrm{~m}, 49.1 \mathrm{~m}, 45.3 \mathrm{~m}$, respectively [Topilski07]. These changes now appear in the $11 / 27 / 07$ deck.

4) CF913 which controls when the FW/BLK heat exchanger for the three FW/BLK intact coolant loops is turned off was changed from $1.32 \mathrm{E}+05$ seconds to $1.0 \mathrm{E}+06$ seconds. However, there was no criterion identified in the [AAS07] for determining when the HX should be shut off.

5) The volume of the TCWS vault (CV133 - Figure 5.3) in the original deck did not agree with the value listed in [SADL07]. The volume in the latest deck was changed from $22970 \mathrm{~m}^{3}$ to $23223 \mathrm{~m}^{3}$ to agree with the data in [SADL07].

6) The volume of the pipe chases and shafts (CV134 - Figure 5.3) in the original deck did not agree with the value listed in [SADL07]. The volume in the latest deck was changed from $16275 \mathrm{~m}^{3}$ to $14784 \mathrm{~m}^{3}$ to agree with the data in [SADL07].

7) The surface area of heat structure hs136 (TCWS walls) in the original deck did not agree with the value listed in [SADL07]. The surface area in the latest deck was changed from $3600 \mathrm{~m}^{2}$ to $4680 \mathrm{~m}^{2}$ to agree with the data in [SADL07].

8) The surface area of heat structure hs137 (TCWS ceiling) in the original deck did not agree with the value listed in [SADL07]. The surface area in the latest deck was changed from $1200 \mathrm{~m}^{2}$ to $1400 \mathrm{~m}^{2}$ to agree with the data in [SADL07]. 
9) The surface area of heat structure hs138 (TCWS floor) in the original deck did not agree with the value listed in [SADL07]. The surface area in the latest deck was changed from $1200 \mathrm{~m}^{2}$ to $1400 \mathrm{~m}^{2}$ to agree with the data in [SADL07].

10) The surface area of heat structure hs 133 (Pipe chase walls) in the original deck did not agree with the value listed in [SADL07]. The surface area in the latest deck was changed from $5600 \mathrm{~m}^{2}$ to $5100 \mathrm{~m}^{2}$ to agree with the data in [SADL07].

11) The surface area of heat structure hs 134 (Pipe chase ceiling) in the original deck did not agree with the value listed in [SADL07]. The surface area in the latest deck was changed from $450 \mathrm{~m}^{2}$ to $1900 \mathrm{~m}^{2}$ to agree with the data in [SADL07].

12) The surface area of heat structure hs 135 (Pipe chase floor) in the original deck did not agree with the value listed in [SADL07]. The surface area in the 11/27/07 deck was changed from $450 \mathrm{~m}^{2}$ to $970 \mathrm{~m}^{2}$.

13) The AAS states that the ex-vessel break is a double ended pipe (ID $=467 \mathrm{~mm}$ ) break in the divertor cooling loop which gives a total break flow area of $0.3426 \mathrm{~m}^{2}$. The original deck had a total break flow area of $0.416 \mathrm{~m}^{2}$ (fl038 and fl039 - Figure 5.3). The 11/27/07 deck now has the correct flow area.

14) The VV nuclear heating vs. timetable (tf700) had a steady state value of $2.6 \mathrm{MW}$. According to [SADL07] the value should be $6.5 \mathrm{MW}$. The 11/27/07 deck now has the correct steady state heating value.

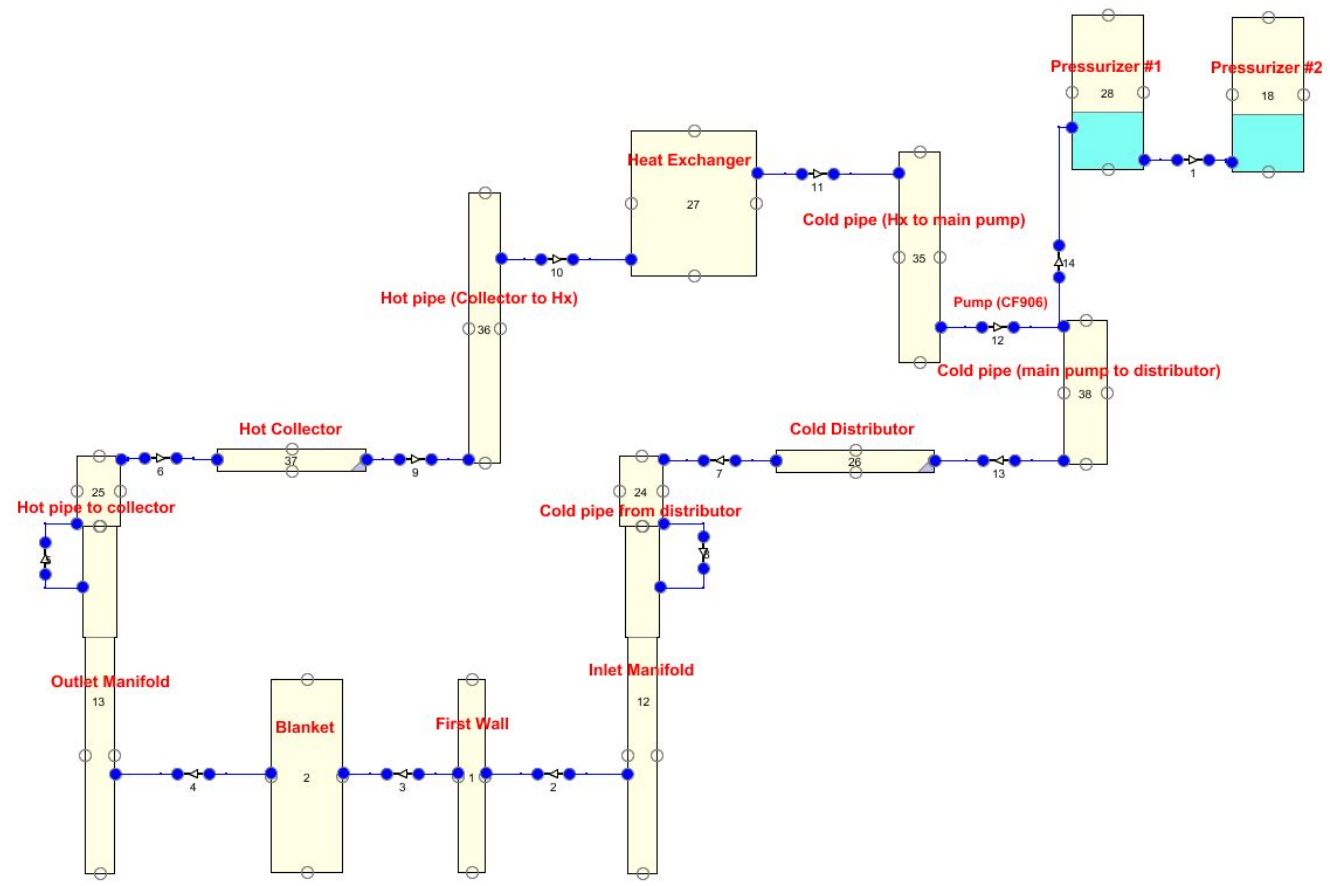

Figure 5-1 FW/BLK Model (three intact loops) in Large Divertor Ex-Vessel Pipe Break Deck 


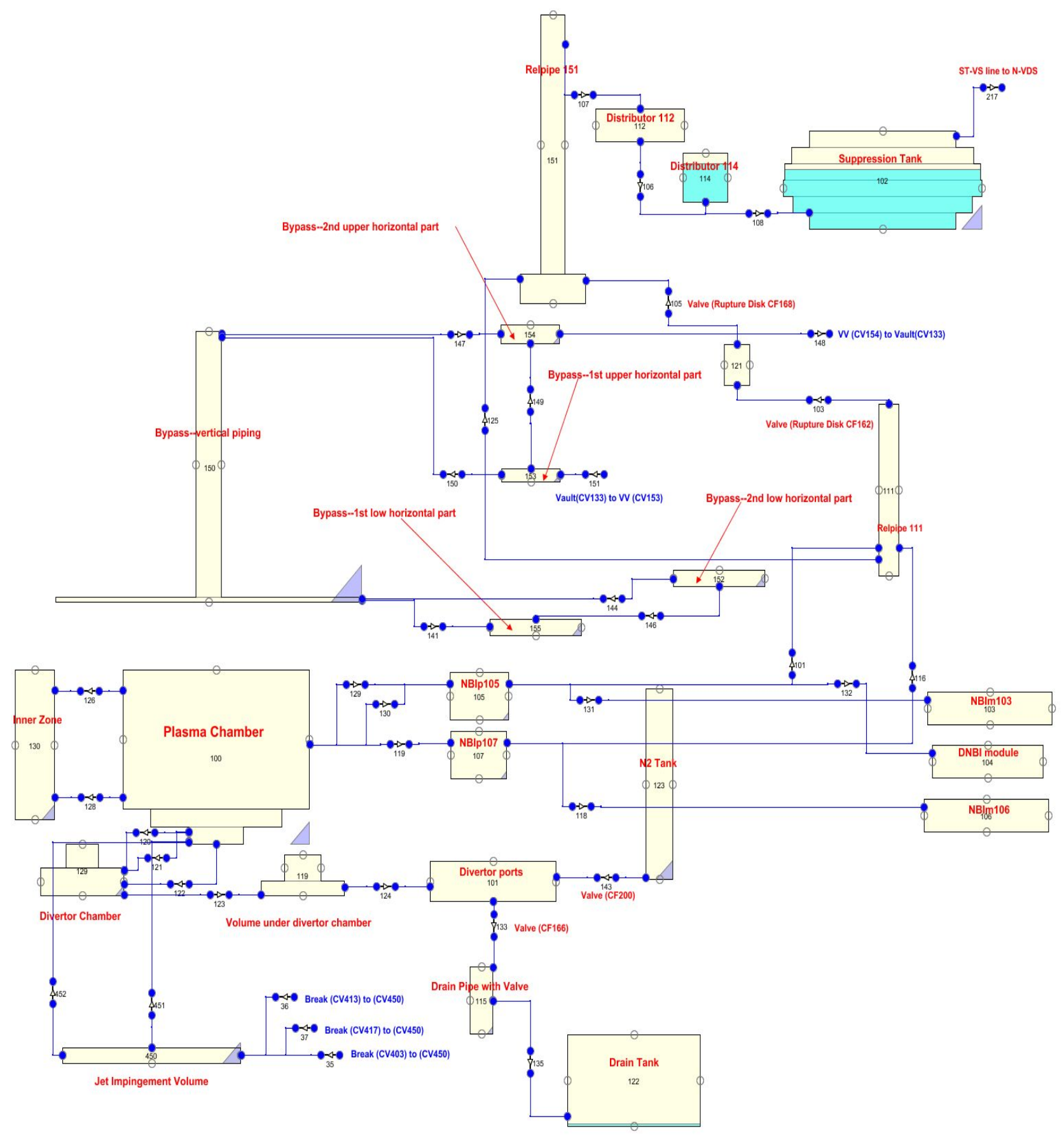

Figure 5-2 VV and Suppression System Model in Large Divertor Ex-Vessel Pipe Break Deck 


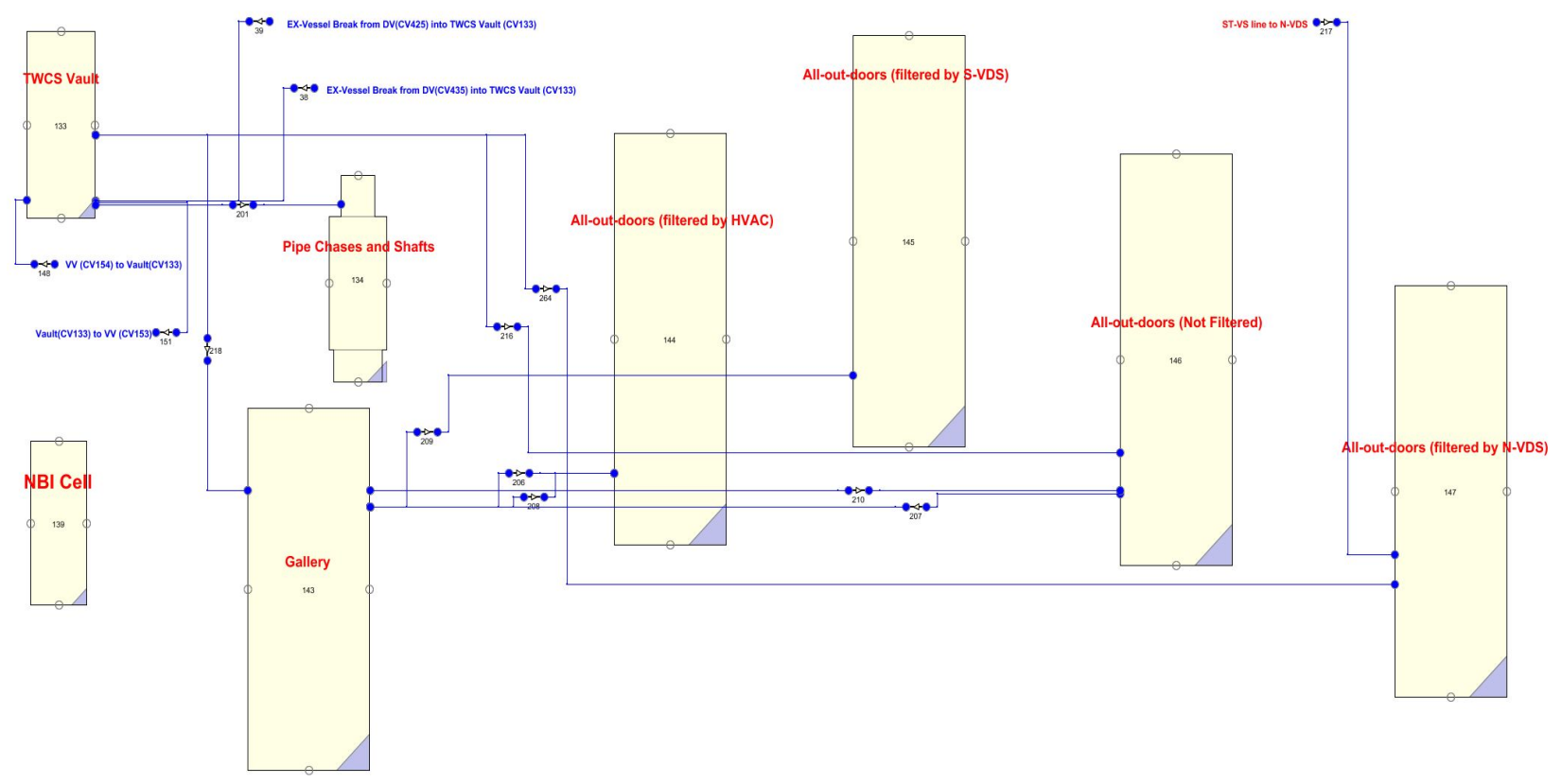

Figure 5-3 Confinement and Vent-Detritiation Model in Large Divertor Ex-Vessel Pipe Break Deck

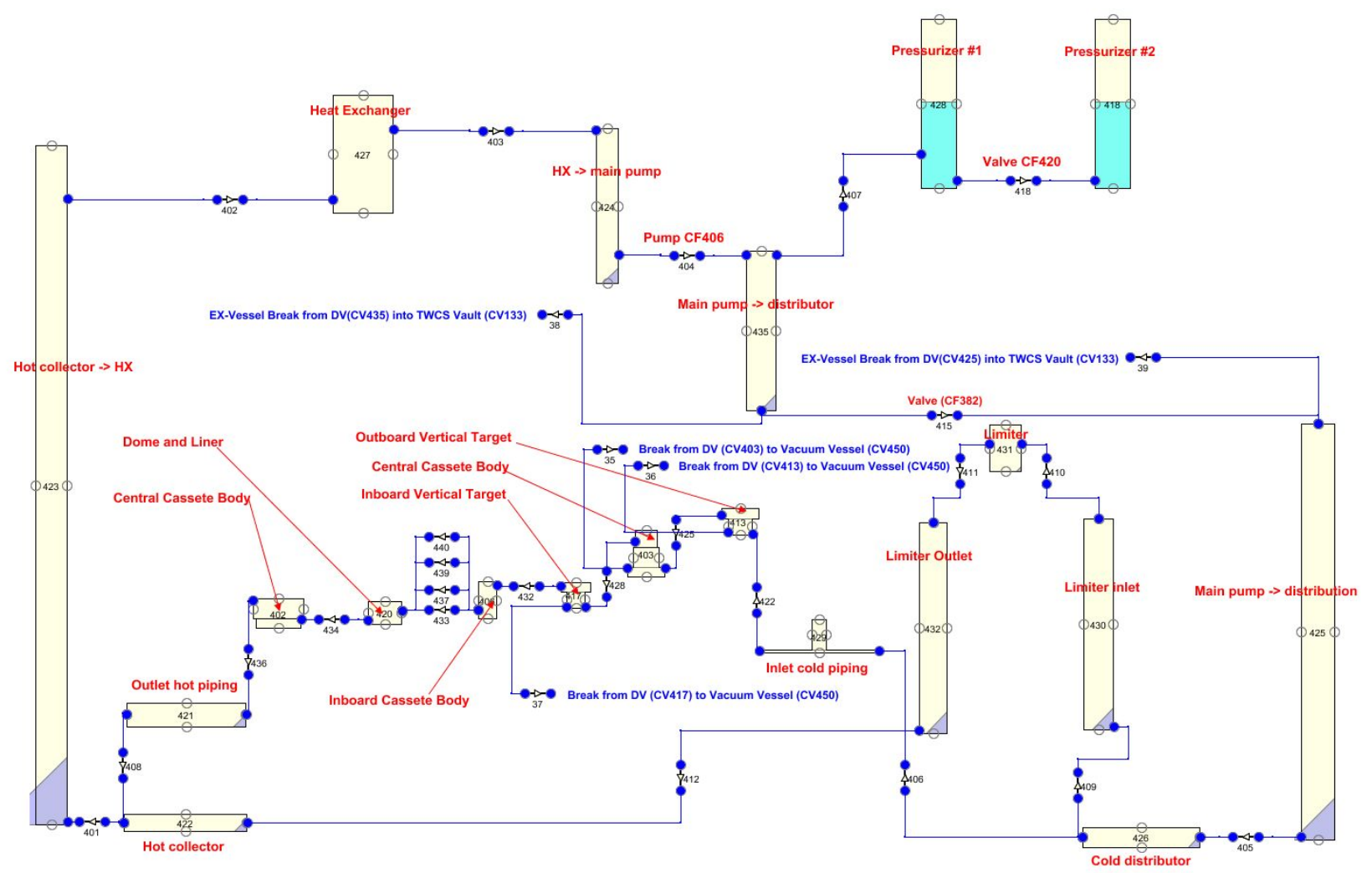

Figure 5-4 Divertor Heat Transport Model in Large Divertor Ex-Vessel Pipe Break Deck 


\section{COMPUTER DECK FOR LOSS OF VACUUM DRY-BYPASS EVENT}

The MELCOR computer deck representing this accident (see [AAS07] for description of accident) consists of five sub-models. The sub-models are: (1) FW/BLK Coolant Loop Model (one intact loops Figure 6.1), (2) FW/BLK Coolant Loop Model (two intact loops - Figure 6.2), (3) Confinement and VentDetritiation system (Figure 6.3), (4) Simplified VVHTS Model (both loops - Figure 2.5). (5) Simplified Divertor heat transport model (Figure 3.2).

The following items listed below were identified as requiring correction in the original deck in order to be in compliance with both the Safety Analysis Data List Version 5.2 [SADL07] and the Accident Analysis Specifications Version 5.2.5 [AAS07] documents. The original deck placed on the ITER IDM system is identified as LossOfVacuumDryBypass_276UY5_1_0.inp. The final version of the deck as of 11/27/07, identified as LossOfVacuumDryBy_ITER_D_276UY $\overline{5} \_v 2$ _.inp was then compared to the original deck to ensure that all the corrections were properly made to this deck.

1) The flow area of FP 1 (Figure 6.1) was found to be incorrect in the original deck. It was changed from $1.18 \mathrm{~m}^{2}$ to $0.59 \mathrm{~m}^{2}$ which is the flow area corresponding to one FW/BLK coolant loop [Topilski07]. The hydraulic diameter was also changed from $0.122 \mathrm{~m}$ to $0.87 \mathrm{~m}$ which corresponds to the one loop flow area $\left(0.59 \mathrm{~m}^{2}\right)$ between pressurizer \#1 (CV028) and pressurizer \#2 (CV018).

2) The lengths of FP fl006s 2, fl007s1, fl009s1, fl013s2 (Figure 6.1) and FP fl906s2, f1907s1, f1909s 1, f1913s2 (Figure 6.2) were determined to be incorrect in the original deck. Their lengths were decreased from $66 \mathrm{~m}$ to $33 \mathrm{~m}$. Because of the reduction in lengths, the total length of f1006, f1007, f1009, f1013, f1907, f1907, f1909, and f1913 are 45.3m, $45.3 \mathrm{~m}, 46.2 \mathrm{~m}$, $49.1 \mathrm{~m}, 45.3 \mathrm{~m}, 45.3 \mathrm{~m}, 46.2 \mathrm{~m}, 49.1 \mathrm{~m}$ respectively [Topilski07].

3) $\mathrm{CF} 013$ (control function 013) which controls when the FW/BLK heat exchanger for the one FW/BLK intact coolant loop is turned off was changed from $1.32 \mathrm{E}+05$ second to $1.0 \mathrm{E}+06$ seconds. What is the criterion to determine when the HX should be shut off.

4) The hydraulic diameter of FP 901 (Figure 6.2) was determined to be incorrect in the original deck. It was changed from $0.122 \mathrm{~m}$ to $0.87 \mathrm{~m}$.

5) CF906 (control function 906) which controls when the FW/BLK heat exchanger for the two FW/BLK intact coolant loops is turned off was changed from $1.32 \mathrm{E}+05$ second to $1.0 \mathrm{E}+06$ seconds. However, there was no criterion identified in the [AAS07] for determining when the HX should be shut off.

6) See item 13 - section 2 .

7) See item $14-$ section 2 .

8) See item $15-$ section 2 .

9) See item $16-$ section 2 .

10) See item $17-$ section 2. 
11) See item $18-$ section 2 .

12) See item $19-$ section 2.

13) See item $23-$ section 2.

14) The volume of the Gallery (CV143 - Figure 6.3) in the original deck did not agree with the value listed in [SADL07]. The volume in the latest deck was changed from $60000 \mathrm{~m}^{3}$ to $72000 \mathrm{~m}^{3}$ to agree with the data in [SADL07].

15) In the $11 / 27 / 07$ deck CF289 is set to open the path to ST-VS at $70 \mathrm{kPa}$ however [SADL07] indicates it should open at $90 \mathrm{kPa}$. This needs to be changed in the next revision of the deck.

16) See item 14 - section 5 .

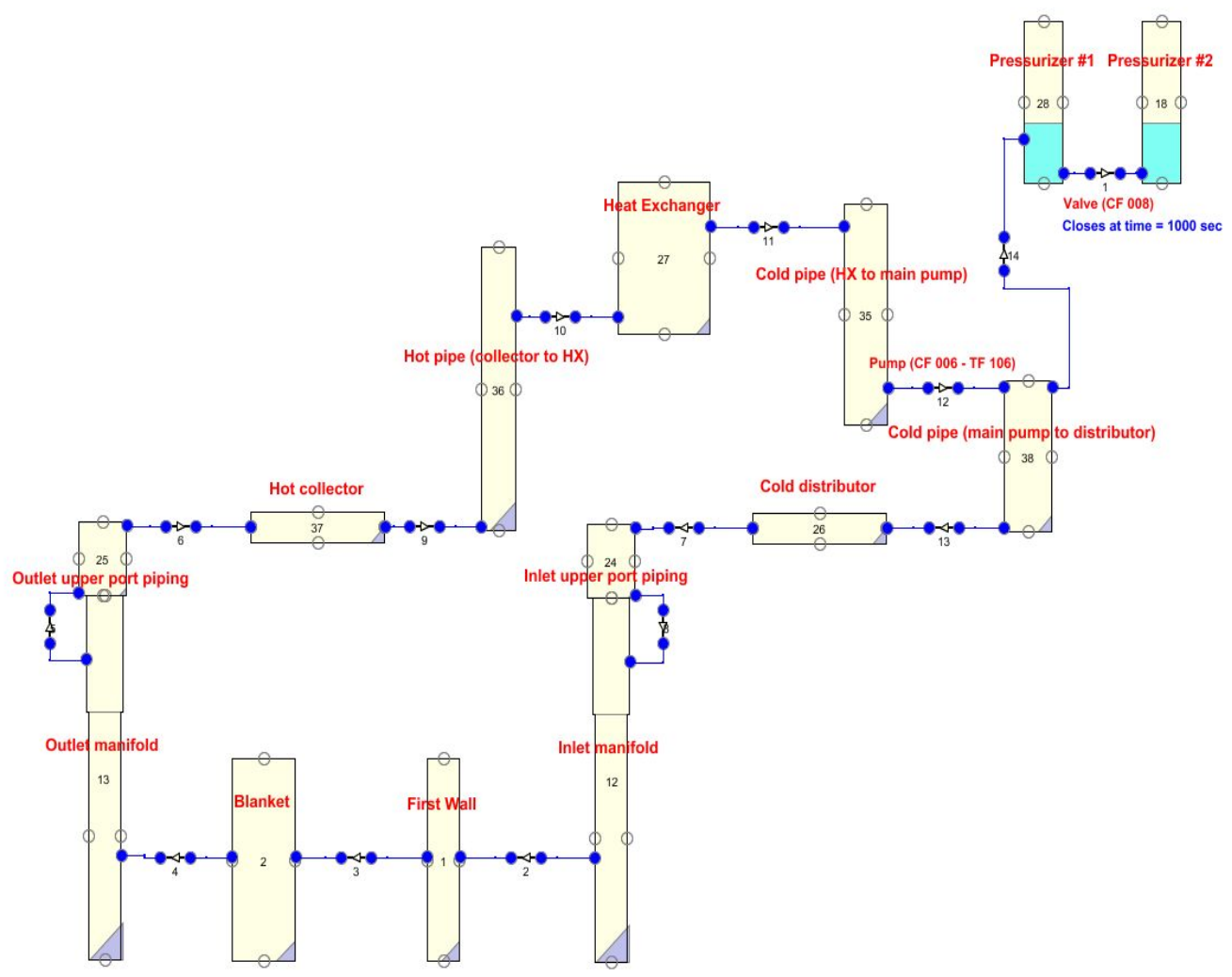

Figure 6-1 FW/BLK Model (one intact loop) in Loss of Vacuum Dry-Bypass Deck 


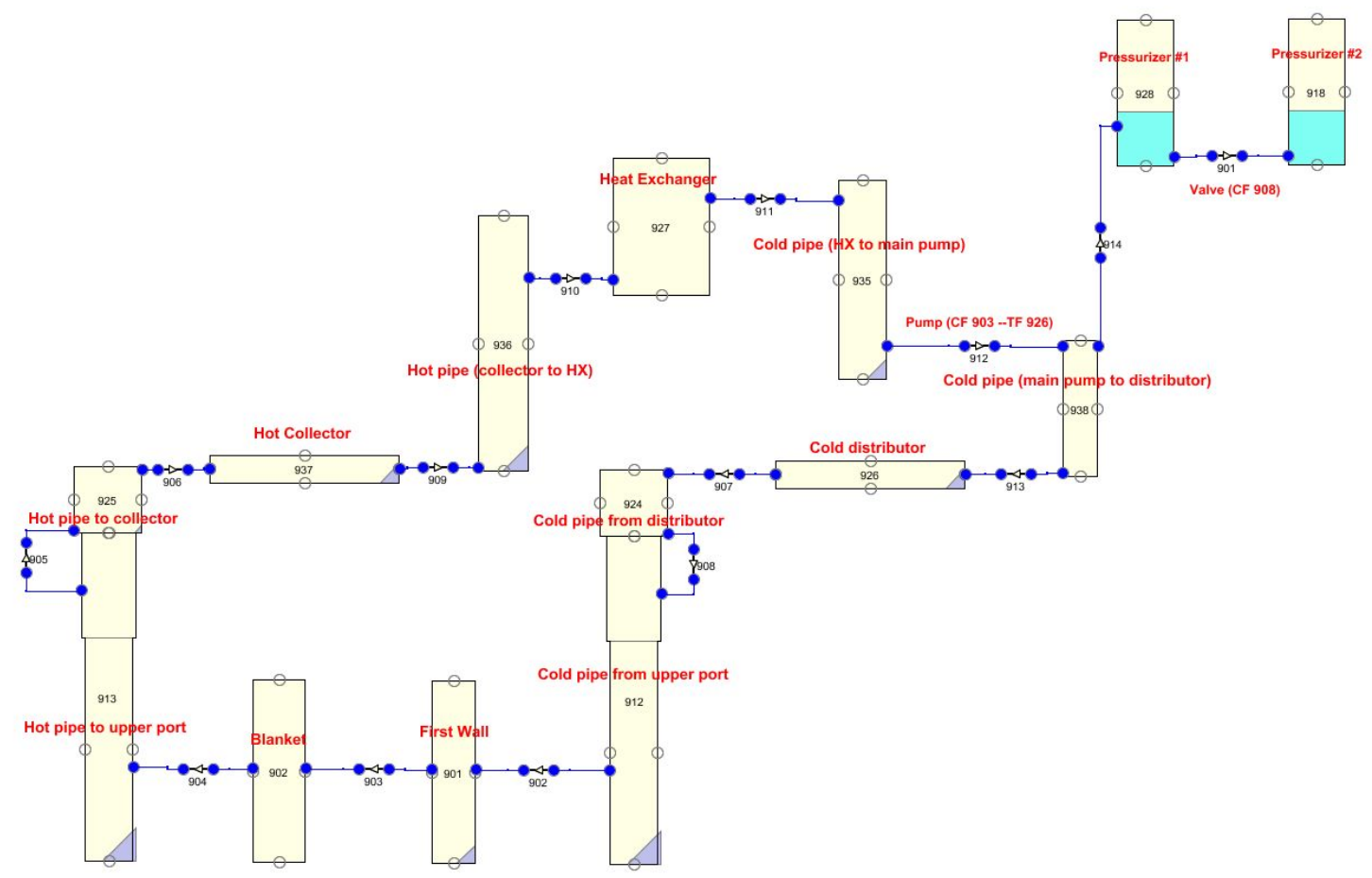

Figure 6-2 FW/BLK Model (two intact loops) in Loss of Vacuum Dry-Bypass Deck

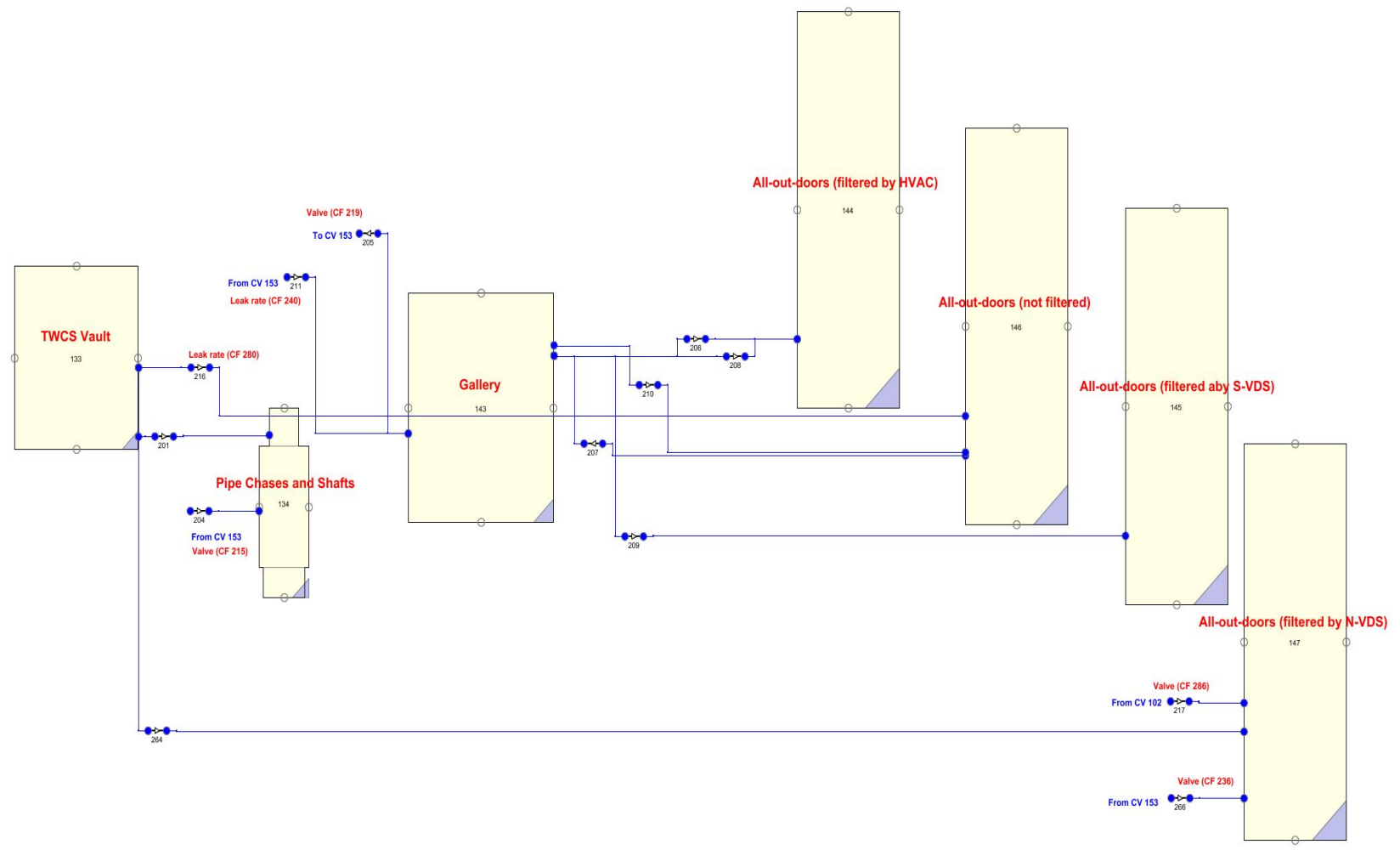

Figure 6-3 Confinement and Vent-Detritiation Model in Loss of Vacuum Dry-Bypass Deck 


\section{COMPUTER DECK FOR MULTIPLE FW PIPE BREAK EVENT}

The MELCOR computer deck representing this accident (see [AAS07] for description of accident) consists of five sub-models. The sub-models are: (1) FW/BLK Coolant Loop Model (three failed loops Figure 7.1), (2) VV and Suppression System Model (Figure 7.2), (3) Confinement and Vent-Detritiation System Model (Figure 7.3), (4). Divertor Loop Model (one loop - Figure 7.4), (5) Simplified VVHTS (both loops - Figure 2.5).

The items listed below were identified as requiring correction in the original deck in order to be in compliance with both the Safety Analysis Data List Version 5.2 ([SADL07]-5.2) and the Accident Analysis Specifications Version 5.2.5 (AAS-5.2.5) documents. The original deck placed on the ITER IDM system is identified as MultipleFWpipeBreak_276UZM_1_0.inp. The final version of the deck as of 11/27/07,

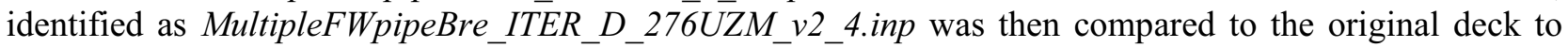
ensure that all the corrections were properly made to this deck.

1) The hydraulic diameter of FP 1 (Figure 7.1) was determined to be incorrect in the original deck. It was changed from $0.127 \mathrm{~m}$ to $0.87 \mathrm{~m}$ in the $11 / 27 / 07$ deck.

2) The lengths of FP fl006s2, f1007s1, f1009s1, and fl013s2 (Figure 7.1) were determined to be incorrect in the original deck. Their lengths were decreased from $66 \mathrm{~m}$ to $33 \mathrm{~m}$. Because of the reduction in lengths, the total length of fl006, fl007, fl009, and fl013, are $45.3 \mathrm{~m}, 45.3 \mathrm{~m}$, $46.2 \mathrm{~m}, 49.1 \mathrm{~m}$ respectively [Topilski07].

3) See item $13-$ section 2 .

4) See item $14-$ section 2 .

5) The volume of the Gallery (CV143 - Figure 7.3) in the original deck did not agree with the value listed in [SADL07]. The volume in the latest deck was changed from $66000 \mathrm{~m}^{3}$ to $72000 \mathrm{~m}^{3}$ to agree with the data in [SADL07].

6) The surface area of heat structure hs136 (TCWS walls) in the original deck did not agree with the value listed in [SADL07]. The surface area in the latest deck was changed from $3600 \mathrm{~m}^{2}$ to $4680 \mathrm{~m}^{2}$ to agree with the data in [SADL07].

7) The surface area of heat structure hs137 (TCWS ceiling) in the original deck did not agree with the value listed in [SADL07]. The surface area in the latest deck was changed from 1200 $\mathrm{m}^{2}$ to $1400 \mathrm{~m}^{2}$ to agree with the data in [SADL07].

8) The surface area of heat structure hs138 (TCWS floor) in the original deck did not agree with the value listed in [SADL07]. The surface area in the latest deck was changed from $1200 \mathrm{~m}^{2}$ to $1400 \mathrm{~m}^{2}$ to agree with the data in [SADL07].

9) The surface area of heat structure hs133 (Pipe chase walls) in the original deck did not agree with the value listed in [SADL07]. The surface area in the latest deck was changed from 5600 $\mathrm{m}^{2}$ to $5100 \mathrm{~m}^{2}$ to agree with the data in [SADL07]. 
10) The surface area of heat structure hs 134 (Pipe chase ceiling) in the original deck did not agree with the value listed in [SADL07]. The surface area in the latest deck was changed from 450 $\mathrm{m}^{2}$ to $1900 \mathrm{~m}^{2}$ to agree with the data in [SADL07].

11) The surface area of heat structure hs135 (Pipe chase floor) in the original deck did not agree with the value listed in [SADL07]. The surface area in the latest deck was changed from 450 $\mathrm{m}^{2}$ to $900 \mathrm{~m}^{2}$; however, it should have been changed to $970 \mathrm{~m}^{2}$ to agree with the data in [SADL07].

12) The original deck had no heat structure for the Gallery walls, ceiling, and floor. Heat structures hs00146, hs00147, and hs00148 were added to the 11/27/07 deck to represent the Gallery walls, ceiling, and floor respectively.

13) See item $14-$ section 5.

14) See item $30-$ section 2.

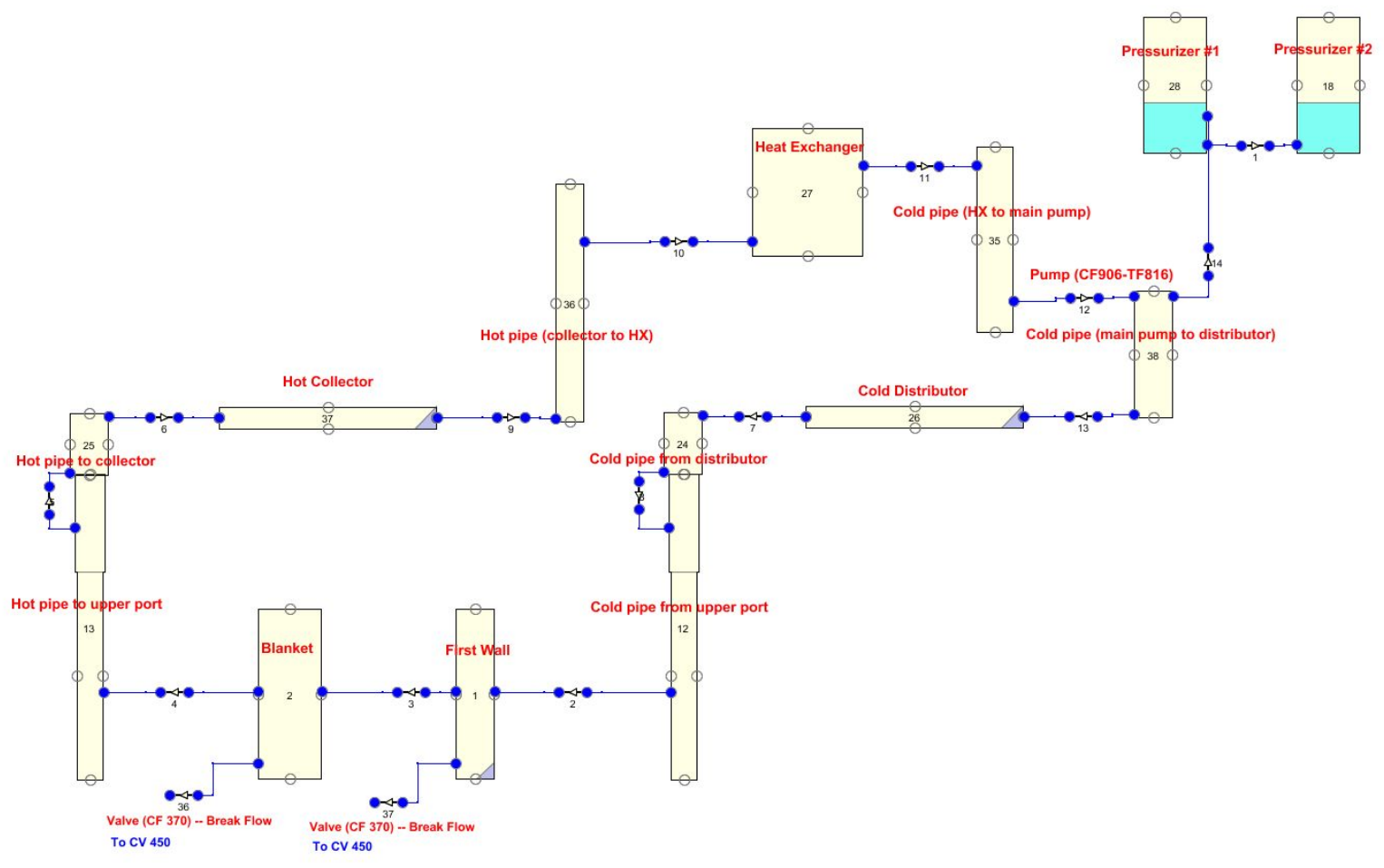

Figure 7-1 FW/BLK Model (three failed loops) in Multiple FW Pipe Break Deck 


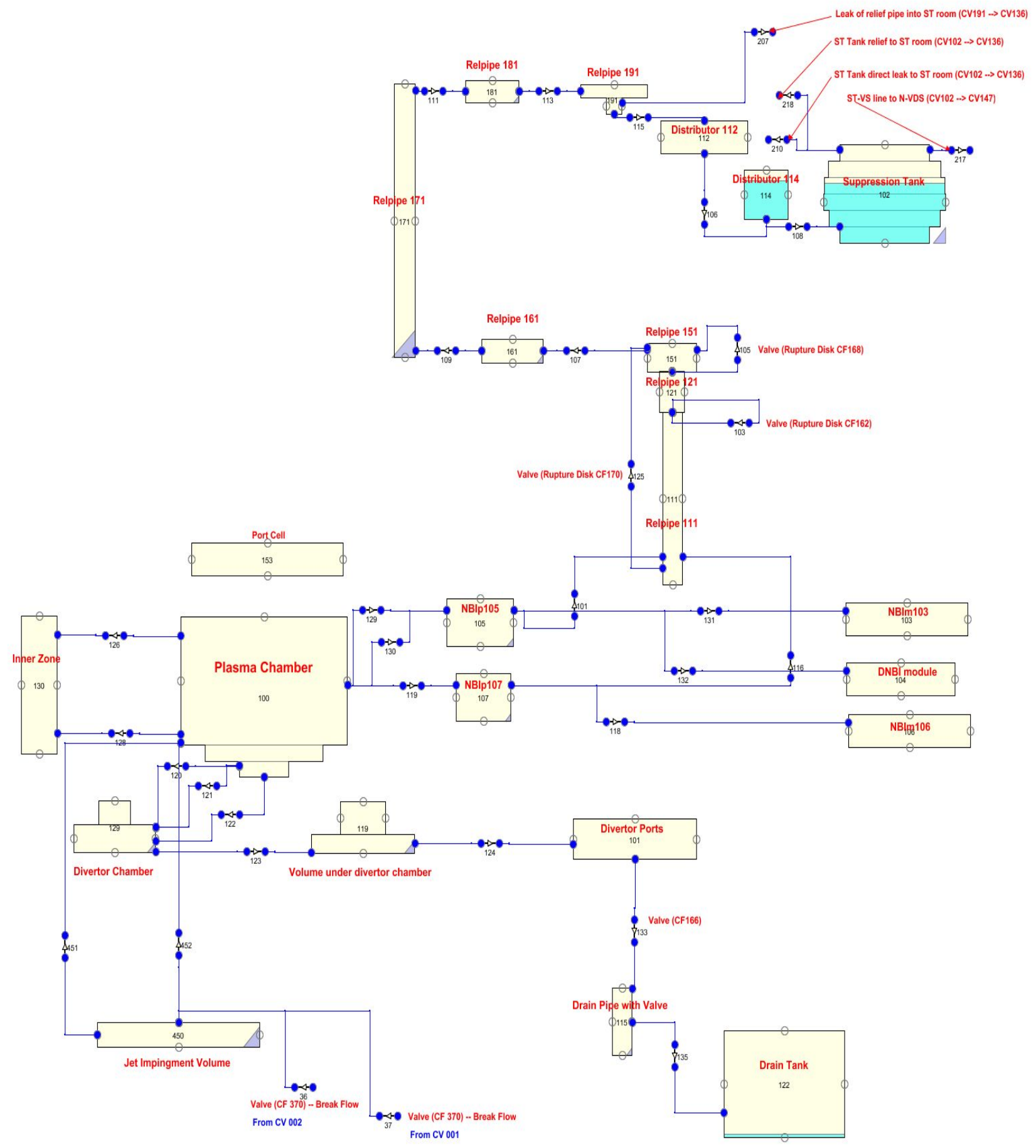

Figure 7-2 VV and Suppression System Model in Multiple FW Pipe Break Deck 


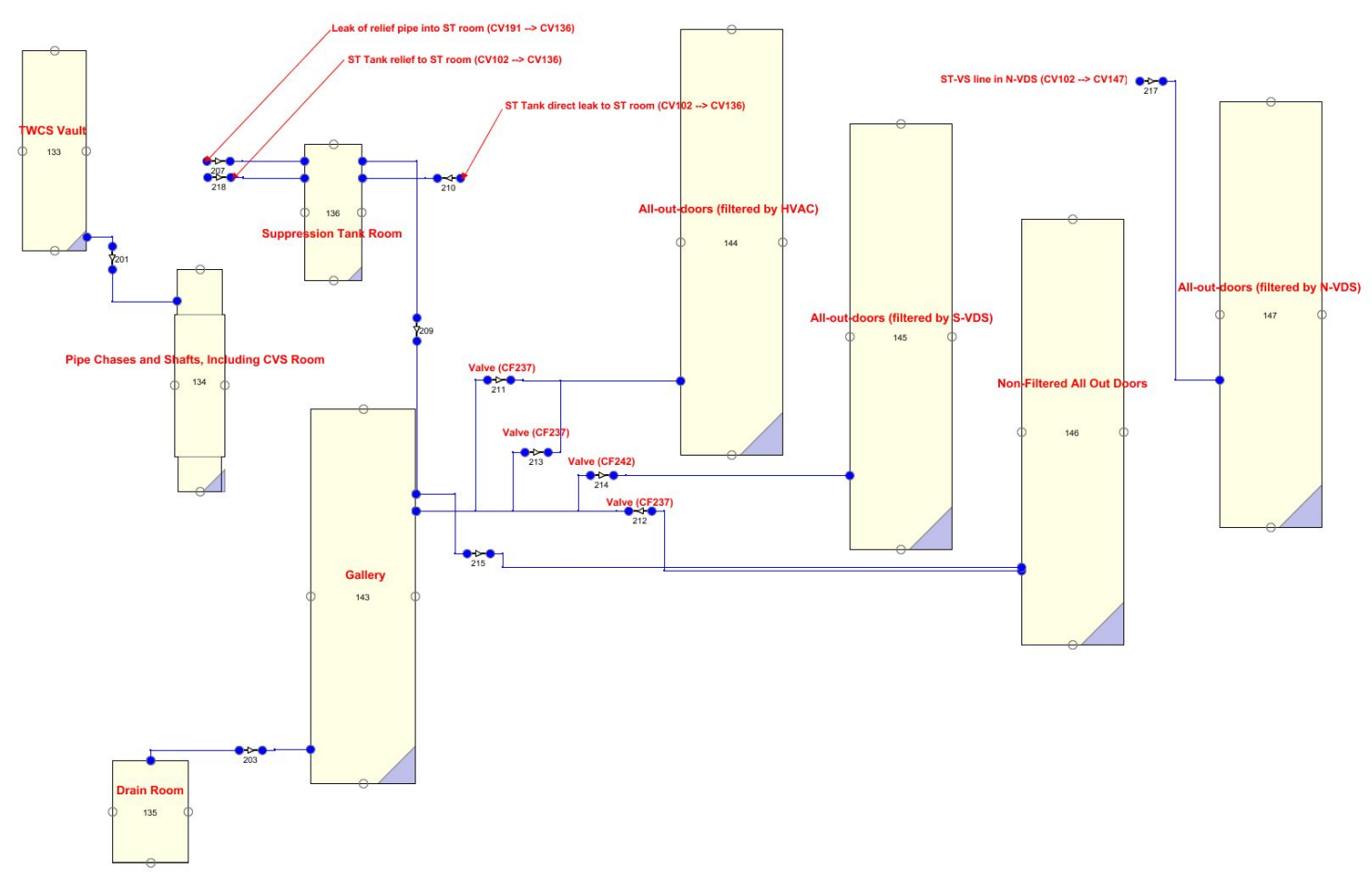

Figure 7-3 Confinement and Vent-Detritiation Model in Multiple FW Pipe Break Deck

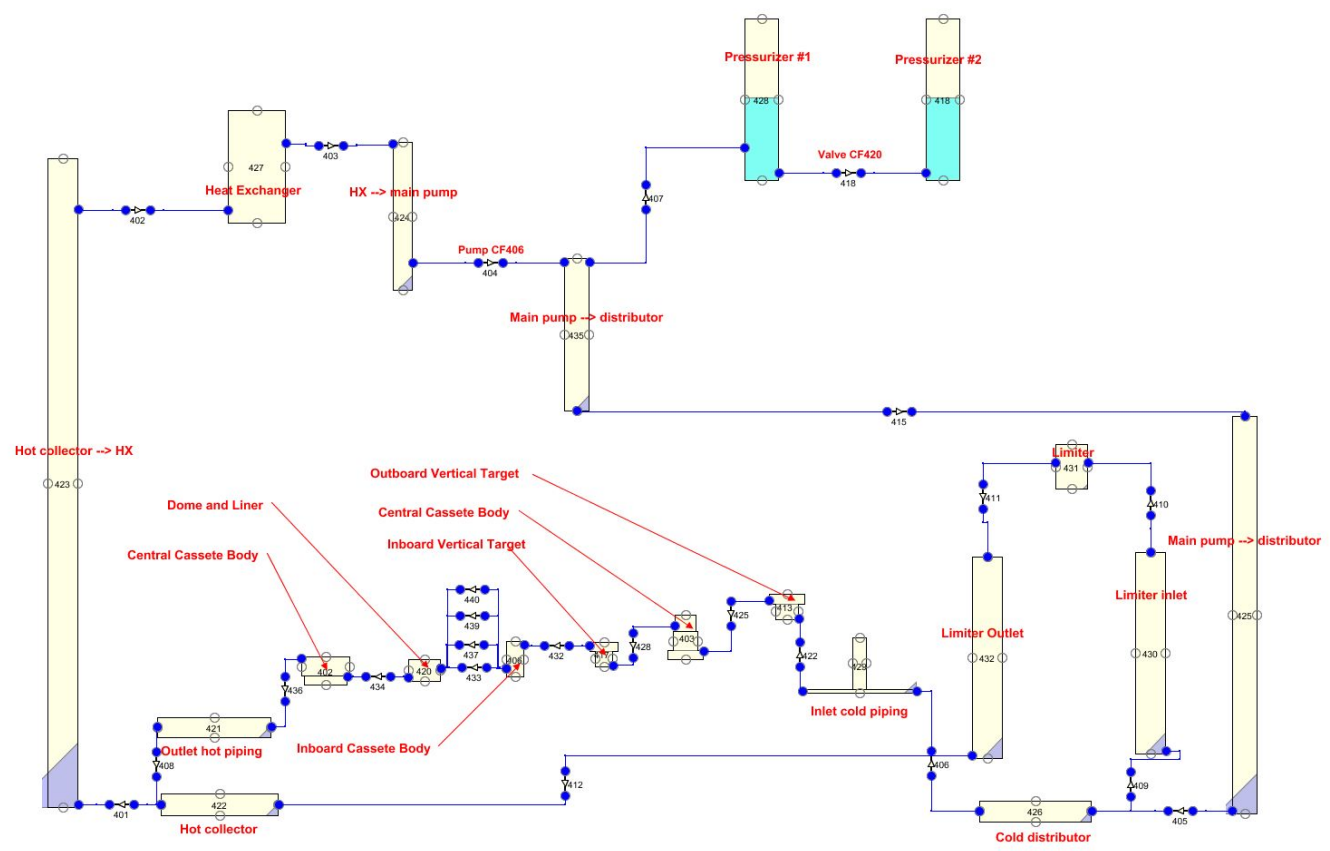

Figure 7-4 Divertor Loop Model (one loop) in Multiple FW Pipe Break Deck 


\section{COMPUTER DECK FOR VACUUM VESSEL CRYOSTAT FAILURE WATER AIR INGRESS EVENT}

The MELCOR computer deck representing this accident (see [AAS07] for description of accident) consists of seven sub-models. The sub-models are: (1) FW/BLK Coolant Loop Model (one intact loop Figure 8.1), (2) FW/BLK Coolant Loop Model (two intact loops - Figure 8.2), (3) VV and Suppression System Model (Figure 8.3), (4). Cryostat Model (Figure 8.4), (5) Confinement and Vent-Detritiation Model (Figure 8.5), (6) VVPHTS Model (both loops - Figure 2.5) and (7) Simplified Divertor Loop Model (Figure $3.2)$.

The items listed below were identified as needing corrected in the original deck in order to be in compliance with both the Safety Analysis Data List Version 5.2 ([SADL07]-5.2) and the Accident Analysis Specifications Version 5.2.5 [AAS07] documents. The original deck placed on the ITER IDM system is identified as VVCryostatFailureWaterAirIngress_276UXL_1_0.inp. The final version of the deck as of 11/27/07, identified as VVCryostatFailure_ITER_D_276UXL_v2_5.inp was then compared to the original deck to ensure that all the corrections were properly made to this deck.

1) The hydraulic diameter of FP 001 (Figure 8.1) was determined to be incorrect in the original deck. It was changed from $0.122 \mathrm{~m}$ to $0.87 \mathrm{~m}$.

2) See item $4-$ section 5 .

3) In the original deck the lower elevation of the drain tank (CV122) was set to $-12.5 \mathrm{~m}$ which did not agree with the elevations of the other decks. In the 11/27/07 deck, the elevation was set to $-11.6 \mathrm{~m}$ which does agree with the other decks.

4) See item $10-$ section 4 .

5) See item $11-\operatorname{section} 4$.

6) The break flow (11/27/07 deck) from the Cryostat into the Cryostat space room (f1915) has the elevation of the break at $4.83 \mathrm{~m}$. The break flow (11/27/07 Cryostat water ingress deck) from the Cryostat into the Cryostat space room (f1915) has the elevation of the break at -0.83 m. Why are these two locations different?

7) The counter flow of f1915 in the $11 / 27 / 07$ deck has the elevation set at $3.17 \mathrm{~m}$ while the elevation in the Cryostat water ingress deck has the elevation set at $0.83 \mathrm{~m}$. Why are these two locations different?

8) See item $12-$ section 4 .

9) See item $29-$ section 2 . 


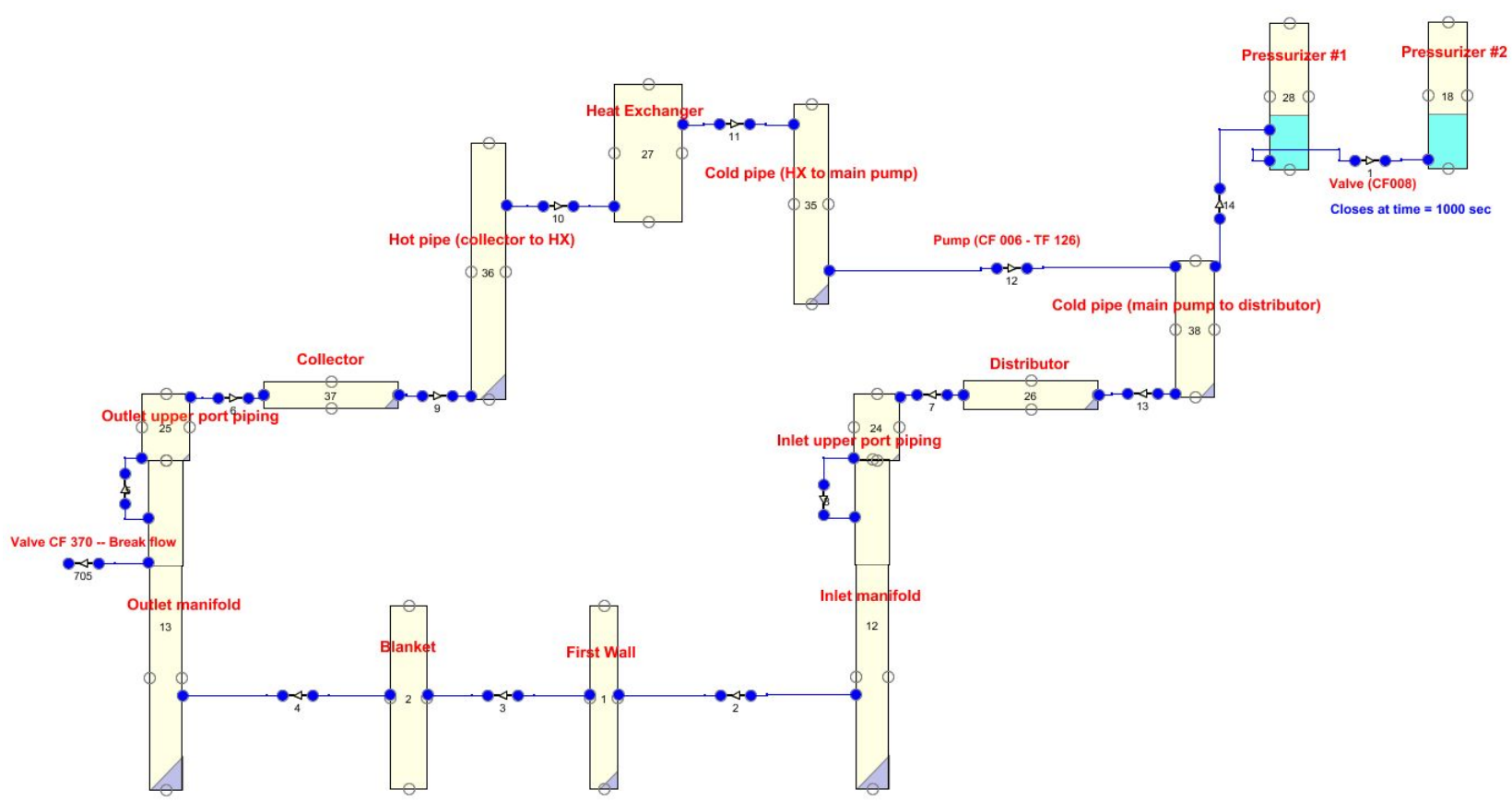

Figure 8-1 FW/BLK Model (failed loop) in VV Cryostat Failure Water Air Ingress Deck

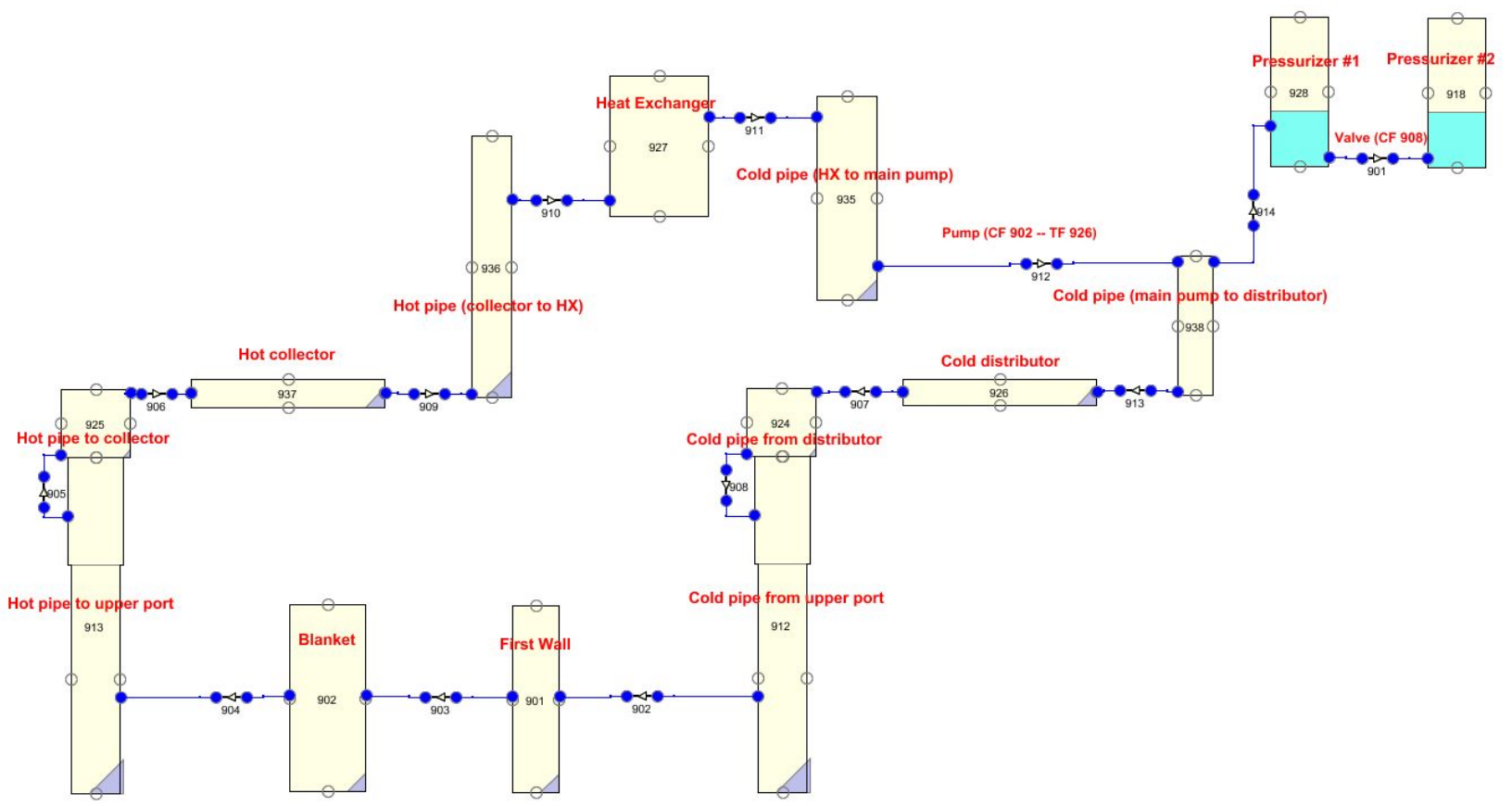

Figure 8-2 FW/BLK Model (two intact loops) in VV Cryostat Failure Water Air Ingress Deck 


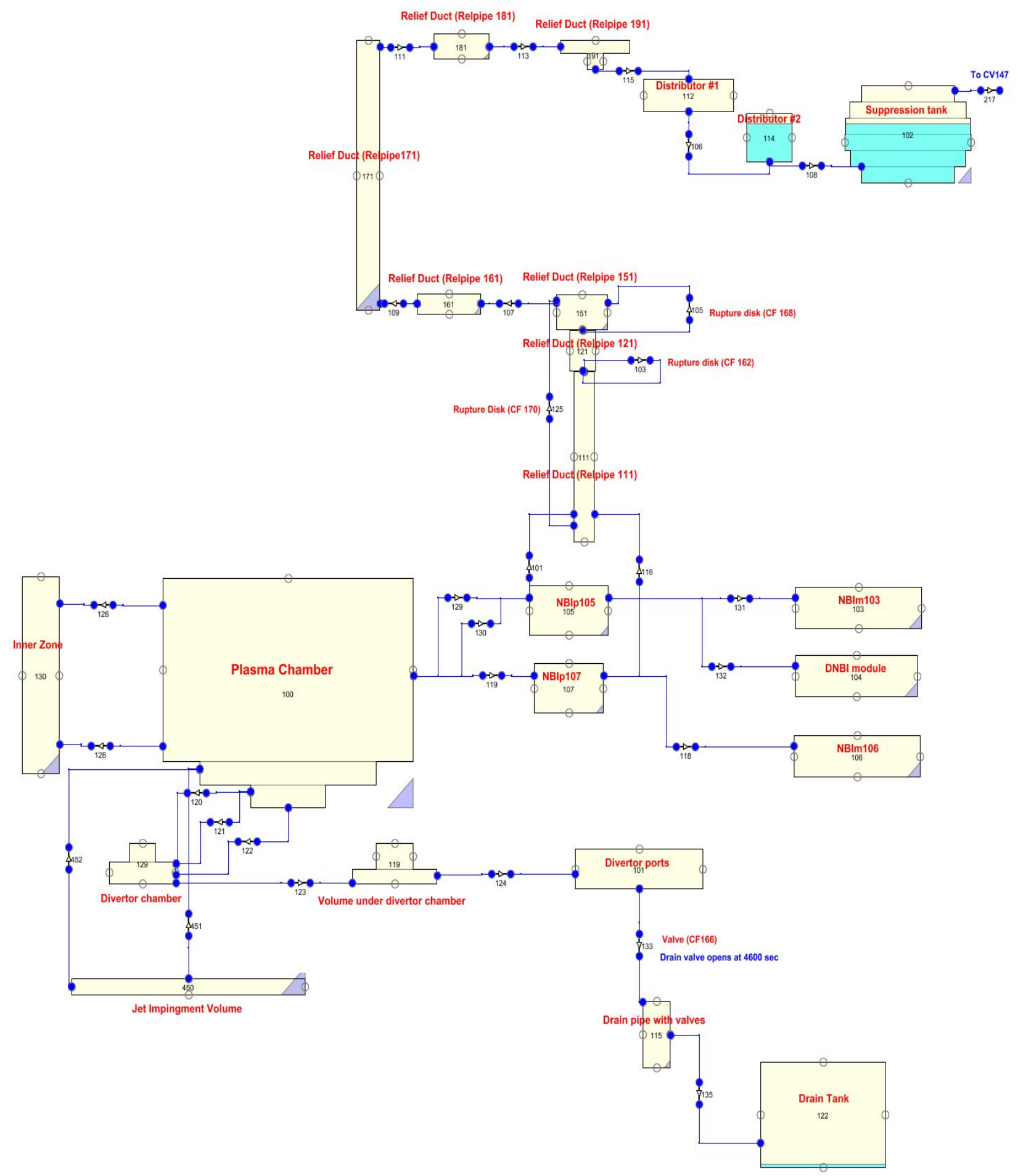

Figure 8-3 VV and Suppression System Model in VV Cryostat Failure Water Air Ingress Deck 


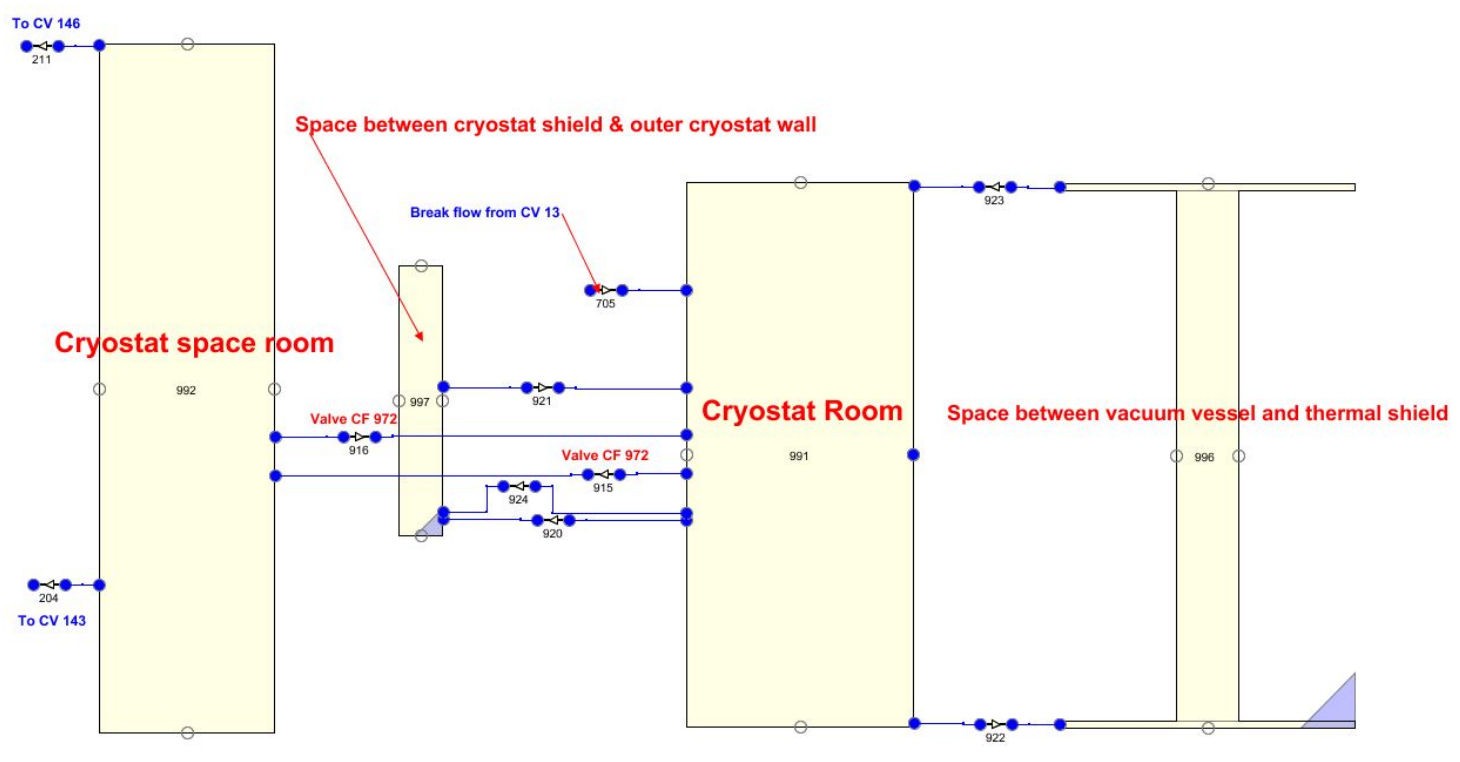

Figure 8-4 Cryostat Model in VV Cryostat Failure Water Air Ingress Deck

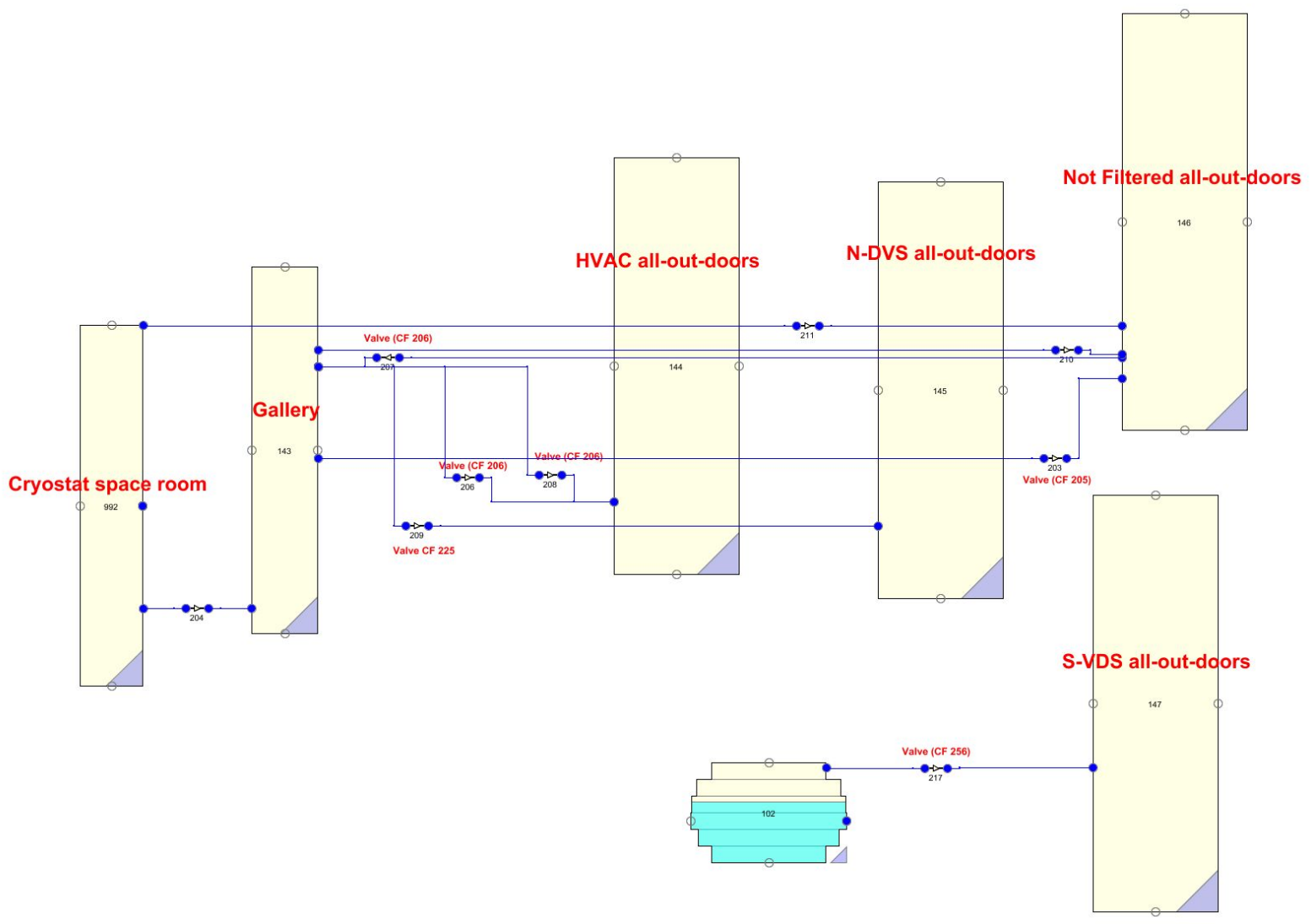

Figure 8-5 Confinement and Vent-Detritiation Model in VV Cryostat Failure Water Air Ingress Deck 


\section{CONCLUSIONS}

The process of verifying that the computer input decks for the analyses to be included in the RPrS conform to the information presented in [SADL07] and [AAS07] has been completed and the findings documented in this report. The results of the verification process found a small number of discrepancies (listed in pervious sections) which have been corrected as of 11/27/07. However, this does not mean that all discrepancies have been found. Given the review procedure and depth of this verification task, a level of practical completeness has been achieved so that any remaining discrepancies are minor and will not significantly affect results from these accident models.

\section{REFERENCES}

[AAS07] Reyes, S. et al., “Accident Analysis Specifications (version 5.2.5)," ITER Document, ITER_D_258QGE, v.2.5, August (2007).

[SADL07] Topilski, L., et al., "Safety Analysis Data List," ITER Report, ITER D 24LSAE, v.2.0, June (2007).

[Sau07] N. Sauthoff, "Support and assistance for MELCOR Quality Assurance and Safety Analyses," ITER Task Agreement, ITA 81-18, TN C81TD30FU, June 3 (2007).

[SNAP07] Symbolic Nuclear Analysis Package, 0.27.0 (Pre-Release) December 20, 2007 (C) 2002-2007 Applied Programming Technology, Inc.

[Topilski07] Topilski, L. "Thermal-Hydraulic Models Used For The ITER Safety Analysis" ITER Document, ITER_D_277XZG v1.0, July (2007). 